\title{
Losy mienia kulturalnego polskich Żydów w okresie okupacji hitlerowskiej i w pierwszych latach powojennych $^{1}$
}

\begin{abstract}
Wstęp
W grudniu 1998 r. czterdzieści cztery państwa - w tym Polska - podpisały tzw. Zasady Waszyngtońskie, których sformułowaniem zakończyła się w stolicy Stanów Zjednoczonych wielka konferencja poświęcona problemom mienia ofiar prześladowań nazistowskich i Holokaustu² ${ }^{2}$ Według tych Zasad muzea, biblioteki i inne instytucje publiczne zobligowane są do starannego sprawdzenia swoich zbiorów pod kątem poszukiwania przedmiotów zagrabionych w okresie nazizmu, niezależnie od tego, kiedy i w jaki sposób znalazły się one w ich posiadaniu. Obiekty o wątpliwym pochodzeniu znajdujące się w zbiorach tych instytucji powinny zostać podane do wiadomości publicznej; należy też podjąć próbę odszukania ich przedwojennych właścicieli lub ich spadkobierców. W przypadku ich odnalezienia instytucje powinny dążyć do uczciwego porozumienia.

W ciągu minionego dziesięciolecia Zasady Waszyngtońskie zaczęto wdrażać w USA, kilku państwach Europy Zachodniej i w Czechach. Każde z tych państw oraz ich instytucje stosują własne metody i działania, osiągając różne rezultaty. Towarzyszy temu obszerna literatura przedmiotu, obejmująca zarówno publikacje naukowe, jak i artykuły prasowe, które przedstawiają opinii publicznej stan badań nad pochodzeniem zbiorów, historyczne i współczesne uwarunkowania tych badań oraz - last but not least - przypadki zwrotu zidentyfikowanych obiektów lub inne formy ugody. Dokumentuje się też kontrowersje i spory między zainteresowanymi stronami.

${ }^{1}$ Niniejszy artykuł jest zmienioną wersją tekstu Dealing with Jewish Cultural Property in Post-war Poland wygłoszonego na konferencji „Jewish Cultural Treasures after the Holocaust. Restitution and Relocation”, Jewish Museum Berlin, 24-25 I 2009 i opublikowanego w „Art, Antiquity and Law”, t. XIV, nr 2, czerwiec 2009, s. 143-166.

${ }^{2}$ Washington Conference on Holocaust-era Assets. November 30 - December 3, 1998. Proceedings, Washington DC 1999, s. 971 n.; wersja polska Zasad Waszyngtońskich w: N. Cieślińska-Lobkowicz, Reprywatyzacja dóbr kultury w Europie ostatniego piętnastolecia, „Muzealnictwo" 2005, t. 46, s. 159 n.
\end{abstract}


Badanie pochodzenia dzieł sztuki i księgozbiorów oraz kwestia ich zwrotu prawowitym właścicielom ma zresztą znaczenie nie tylko moralne, polityczne i prawne. W państwach, w których zgodnie z Zasadami Waszyngtońskimi takie badania są prowadzone, zaowocowały one odkryciem nieznanych, zapomnianych lub przemilczanych kart historii okresu nazizmu, w szczególności historii Zagłady, a także okresu powojennego.

W tym kontekście tym bardziej dotkliwy jest brak badań nad losami ruchomego mienia kulturalnego zagrabionego Żydom podczas II wojny światowej na terenie Europy Wschodniej, a więc tam, gdzie żyła większość ofiar Szoa. Ogromna część należących do nich dzieł sztuki i dóbr kultury została przez Niemców zniszczona, wiele z nich - wśród nich najwartościowsze - wywieziono do Rzeszy, reszta pozostała na miejscu. Tu odnalezione, trafiały różnymi drogami i w różnych latach do zbiorów publicznych w Polsce, Rosji, państwach nadbałtyckich i na Ukrainie. Rządy tych państw podpisały Zasady Waszyngtońskie, ale do dziś nie uczyniły nic lub prawie nic, aby ich instytucje kultury zaczęły się stosować do podjętych w $1998 \mathrm{r}$. zobowiązań.

W przypadku Polski Zasady Waszyngtońskie posłużyły dotychczas jedynie jako polityczny instrument w staraniach o zwrot zidentyfikowanych za granicą obiektów zrabowanych w okresie okupacji z polskich kolekcji publicznych ${ }^{3}$. Wykazy strat wojennych, po kilkudziesięcioletniej przerwie zestawiane na nowo w początku lat dziewięćdziesiątych XX w. w ministerstwie kultury, służyć miały przede wszystkim poszukiwaniu i identyfikacji w obcych zbiorach zabytków wywiezionych z kraju w czasie wojny. Zagrabione lub zniszczone dobra kultury Żydów polskich występują w tych wykazach sporadycznie. Pisze się o nich en passant i wyłącznie ogólnikowo zarówno w dawnych, jak i nowych krajowych publikacjach na temat hitlerowskiej grabieży dóbr kultury w Polsce i ich powojennej restytucji.

Niniejszy artykuł jest próbą zasygnalizowania tego zaniedbanego tematu. Składa się z trzech części. Pierwsza przedstawia krótki i bardzo ogólny zarys sytuacji Żydów polskich i ich zainteresowań kolekcjonerskich przed wybuchem II wojny światowej. Następnie charakteryzuję politykę nazistów wobec dóbr kultury w okupowanej Polsce i wskazuję, że także w tym zakresie Żydów represjonowano znacznie bardziej bezwzględnie niż ich polskich sąsiadów. Ostatnia część to syntetyczny opis, jak potraktowano uratowane żydowskie dobra kultury i ich prawowitych właścicieli w Polsce tuż po wojnie, czyli na etapie pierwszej fali restytucji, zakończonej praktycznie na początku lat pięćdziesiątych.

${ }^{3}$ Patrz strona internetowa Polskiego Ministerstwa Spraw Zagranicznych: www.msz.gov. $\mathrm{pl} /$ rewindykacje. 


\section{Okres przedwojenny}

W 1939 r. w Polsce mieszkało prawie 3,5 mln. Żydów, co stanowiło ok. 10 proc. całej ówczesnej ludności kraju4 . Jidysz był pierwszym językiem co najmniej 75 proc. polskich Żydów ${ }^{5}$. W zdecydowanej większości mieszkali oni w miastach. W większych ośrodkach miejskich stanowili zazwyczaj co najmniej jedną trzecią ogółu mieszkańców. W Warszawie żyło 380 tys. Żydów (była to wówczas najliczniejsza społeczność żydowska w Europie i druga na świecie po Nowym Jorku), w Łodzi 230 tys., w Krakowie - 60 tys., w Lublinie - 42 tys. ${ }^{6} \mathrm{~W}$ mniejszych miastach Polski centralnej, wschodniej i południowej odsetek ten był jeszcze wyższy: w Rzeszowie mieszkało 19 tys. Żydów (co stanowiło 47 proc. mieszkańców miasta), w Tarnowie - 25 tys., w Oświęcimiu - 7 tys. (odpowiednio 48 i 58 proc. mieszkańców). W tak zwanych sztetlach odsetek ten przekraczał nawet 60-70 proc. (przykładem może być Pińczów i Działoszyce, każde z 3,5 tys. ludności żydowskiej w 1939 r.). Zdecydowana większość polskich Żydów była stosunkowo biedna i utrzymywała się z drobnego handlu (ponad 80 proc. Żydów było krawcami, szewcami, drobnymi kupcami lub domokrążcami). W większych miastach Żydzi mieszkali zazwyczaj w dzielnicach tradycyjnie żydowskich, które nierzadko powstały w miejscu dawnych gett. Zamożniejsi natomiast przeprowadzali się chętnie do bardziej prestiżowych i eleganckich dzielnic.

Począwszy od drugiej połowy XIX w. wyemancypowani Żydzi odgrywali coraz większą rolę w polskiej gospodarce, kulturze i nauce. Podobnie jak w Niemczech i innych państwach Europy Zachodniej, część Żydów podążyła ścieżką wytyczoną przez Haskalę. Porzucali tradycyjny styl życia diaspory na rzecz nowego „otwartego” modelu żydostwa, wykonywali nieosiągalne wcześniej dla Żydów zawody, praktykowali judaizm reformowany, nierzadko asymilowali się, współtworząc nowoczesną elitę kraju.

Na kilka lat przed wybuchem II wojny światowej przedsiębiorstwa należące do Żydów zatrudniały znaczną część przemysłowej siły roboczej. Żydzi odgrywali istotną rolę w finansach, bankowości, transporcie oraz w nowoczesnym handlu ery przemysłowej. Co piąty student polskich wyższych uczelni był Żydem. Co najmniej 6 proc. Żydów wykonywało wolne zawody: byli naukowcami, lekarzami, prawni-

${ }^{4}$ Podane tu szacunkowe dane i liczby dotyczące ludności żydowskiej w Polsce pochodzą z różnych aktualnych publikacji na ten temat. Zasadniczo pomijam w tym opracowaniu przykłady z terenów wschodnich RP, które znajdują się poza obecnym terytorium państwa polskiego, podobnie zresztą nie uwzględniam odrębnej problematyki ziem zachodnich.

${ }^{5}$ The Black Book of Polish Jewry. An Account of the Martydom of Polish Jewry Under the Nazi Occupation, red. J. Apenszlak, New York 1943, s. 297. Zob. też: D. Pohl, Nationalsozialistische Judenverfolgung in Ostgalizien 1941-1944. Organisation und Durchführung eines staatlichen Massenverbrechens, München 1996, s. 24.

${ }^{6}$ Tylko na zachodnich terenach II Rzeczypospolitej, przed 1918 r. będących częścią Prus, odsetek ludności żydowskiej w ogóle, a także wśród mieszkańców miast, był znacznie niższy. 
kami, dziennikarzami, wydawcami, uprawiali zawody artystyczne i profesjonalnie zajmowali się polityką, nie mówiąc o nauczycielach uczących w tradycyjnie ortodoksyjnych chederach i jesziwach, ale także w rosnącej liczbie nowoczesnych szkół żydowskich. Jedni członkowie inteligencji i burżuazji żydowskiej pozostawali wierni tradycji żydowskiej lub współtworzyli jej nowe oblicze, inni wiązali się z polską kulturą, a nierzadko jedno szło w parze z drugim. Tak czy inaczej, kultura stanowiła ważne pole ich działalności. Wydawnictwa, prasa oraz film - zarówno dla Żydów, jak Polaków - w znacznej mierze stanowiły ich zawodową domenę; podobnie księgarstwo i rynek sztuki.

W przedwojennej Polsce istniały setki synagog, domów modlitwy, bat midraszy. Znajdowały się w nich, obok świętych zwojów Tory, liczne, nierzadko cenne księgozbiory o tematyce religijnej oraz przedmioty rytualne, wśród nich obiekty o wielkiej wartości historycznej i artystycznej, nie mówiąc o pinchasach z archiwów kahalnych. Istniało też wiele bibliotek różnych świeckich organizacji żydowskich, a także cenne księgozbiory prywatne. Znani żydowscy kolekcjonerzy sztuki słynęli z tego, że wypożyczali lub ofiarowywali swoje dzieła galeriom i muzeom państwowym. Często też wspierali studia i karierę artystów, zarówno żydowskich, jak i polskich.

Ten opis można zilustrować wybranymi przykładami i liczbami ${ }^{7} \mathrm{~W}$ dwudziestoleciu międzywojennym 2560 żydowskich szkół religijnych na terenie Polski (w samej Warszawie było trzysta chederów, tj. religijnych szkół podstawowych) zgromadziło w swoich bibliotekach około 250 tys. tomów. Żydowskie Stowarzyszenie Kulturalno-Oświatowe Tarbut założyło sieć 425 bibliotek publicznych, w których znajdowało się 290 tys. różnojęzycznych książek; robotnicy uczęszczający na kursy wieczorowe mogli korzystać z 264 bibliotek utworzonych przez Kulturlige. Także Szulkut i inne żydowskie stowarzyszenia oświatowe i kulturalne posiadały setki bibliotek. W 251 większych bibliotekach żydowskich (tzn. posiadających ponad tysiąc tomów) zgromadzono co najmniej 1 mln 650 tys. książek.

Warto wymienić kilka ważnych przedwojennych bibliotek żydowskich działających w obrębie dzisiejszych granic Polski (a więc z pominięciem wybitnych bibliotek Wilna i Lwowa). Wśród książnic publicznych - nota bene żadna nie była finansowana czy choćby wspierana przez państwo polskie - największa była Główna Biblioteka Judaistyczna przy Wielkiej Synagodze na Tłomackiem w Warszawie

7 Podane dane i liczby opierają się przede wszystkim na: The Black Book of Polish Jewry..., s. 280-313; Tentative List of Jewish Cultural Treasures in Axis-occupied Countries [sporządzona przez Commission on European Jewish Cultural Reconstruction], New York 1946; Ch. Estreicher, Cultural Losses of Poland. Index of Polish Cultural losses during the German occupation 1939-1944, London 1944 (wyd. polskie: K. Estreicher, Straty kultury polskiej pod okupacja niemiecka wraz z oryginalnymi dokumentami grabieży, Kraków 2003); B. Bieńkowska, Informator o stratach bibliotek i księgozbiorów domowych na terytoriach polskich okupowanych w latach 1939-1945, Poznań 2000. Zob. też E. Chwalewik, Zbiory polskie. Archiwa, biblioteki, gabinety, galerje, muzea i inne zbiory pamiątek przeszłości w ojczyźnie i na obczyźnie, Warszawa 1926, t. 1-2 [przedruk: Kraków 1991]. 
(40 tys. tomów) ${ }^{8}$. Biblioteka Ezra przy krakowskiej gminie (6 tys. tomów) była jedną z najstarszych ${ }^{9}$. Najnowocześniejsze były: łódzka Biblioteka im. Borochowa, białostocka Biblioteka im. Szolema Alejchema (46 tys. tomów) oraz biblioteka Uczelni Mędrców Lublina (32 tys. tomów) ${ }^{10}$.

Znakomite księgozbiory prywatne zgromadzili m.in. profesorowie Majer Bałaban (5 tys. tomów) i Mojżesz Schorr (3 tys.), poeta Julian Tuwim (12 tys.), językoznawca Max Weinreich (8,5 tys.), przemysłowiec Leopold Wellisz (11 tys.) i znani bibliofile, jak Ludwik Simon, Ludomil Lewenstam czy Samuel Dickstein. Nie można tutaj nie wspomnieć o słynnych żydowskich księgarzach z ulicy Świętokrzyskiej w Warszawie - Salcsteinach, Kleinsingerach i Rubinsteinach, czy ze Szpitalnej w Krakowie - jak Himmelblau, Seiden i Taffet.

Wybitne kolekcje judaików stworzyli Mieczysław Zagajski, Samuel Goldflamm, Benjamin Mintz i in. Właściciel jednej z najcenniejszych, Maksymilian Goldstein ze Lwowa, udostępniał ją w swoim mieszkaniu mającym charakter prywatnego muzeum ${ }^{11}$.

Najstarsze muzeum żydowskie w Polsce powstało w 1905 r. w budynku Żydowskiej Gminy Wyznaniowej w Warszawie dzięki darowiźnie Mathiasa Bersohna. W chwili wybuchu II wojny światowej posiadało w swoich zbiorach kilkaset synagogaliów i obiektów kultu domowego, obrazy żydowskich artystów oraz ponad tysiąc ksiąg i rękopisów judaistycznych. Niewiele później judaika zaczęło gromadzić także założone w 1913 r. Towarzystwo Historyczno-Etnograficzne im. An-skiego w Wilnie. W latach trzydziestych gminy żydowskie w Krakowie, Lwowie, Łodzi i Poznaniu, a także wileński Jidiszer Wisnszaftlecher Institut (YIVO) również poczęły zbierać do zakładanych lub planowanych muzeów różnego rodzaju religijne i świeckie judaika.

Do zapalonych kolekcjonerów sztuki, głównie dzieł polskich i żydowskich malarzy, ale także płócien starych mistrzów, należeli obok Zagajskiego - by ograniczyć się do Warszawy - Franciszek Goldberg-Górski, Bronisław Krystall, Leopold Kronenberg, Stanisław Meyer, Edward Natanson, Andrzej Rotwand i Leopold Wellisz. Na zorganizowanej w 1932 r. w Krakowie wystawie Maurycego Gottlieba ponad siedemdziesiąt płócien pochodziło z prywatnych zbiorów żydowskich. Także przedwojenne katalogi wystaw Jacka Malczewskiego, Józefa Mehoffera, Leona Wyczółkowskiego czy Teodora Axentowicza dowodzą, że w kręgach inteligencji i burżuazji żydowskiej ich płótna były wysoko cenione i chętnie nabywane.

${ }^{8}$ „W Warszawie było pięćdziesiąt żydowskich bibliotek, posiadających łącznie 263336 tomów" - The Black Book of Polish Jewry..., s. 300.

${ }^{9}$ Według The Black Book of Polish Jewry..., s. 301: „Krakowskie biblioteki »Ezra« oraz I.I. Pereca miały 20 tys. tomów”.

${ }^{10}$ Zob. też J. Borin, Embers of the Soul: The Destruction of Jewish Book and Libraries in Poland during World War II, „Journal of Library History, Libraries and Culture” 1993, nr 4, s. 445-460.

${ }^{11}$ M. Goldstein, K. Dresdner, Kultura i sztuka ludu żydowskiego na ziemiach polskich. Zbiory Maksymiliana Goldsteina, Lwów 1935 [przedruk: Warszawa 1991]. 
Stanisław Lorentz, wieloletni dyrektor Muzeum Narodowego w Warszawie, zwykł wspominać, że gdy w 1937 r. apelował o dary rzeczowe do nowo otwartego gmachu muzeum, liczył głównie na odzew arystokracji. Ta jednak pozostała obojętna na jego apel, w przeciwieństwie do żydowskich mecenasów i zbieraczy, wśród których szczególnie hojny okazał się Krystall ${ }^{12}$.

Na krótko przed wybuchem wojny i w jej początkach niektóre prywatne kolekcje zostały oddane w depozyt do Muzeum Narodowego w Warszawie lub tam ukryte. Żydowscy właściciele, wśród których byli Krystall, Leopold Binenthal, Ignacy Landstein, siostry Golberg-Górskie, ustalili z dyrektorem Lorentzem, że przekazane przez nich obiekty będą traktowane pro forma jako dary dla muzeum albo ich pochodzenie zostanie sfingowane, aby zapobiec hitlerowskiej konfiskacie ${ }^{13}$. Inne osoby zagrożone $z$ powodu pochodzenia oddawały swoje zbiory obrazów i wyrobów sztuki użytkowej na przechowanie polskim przyjaciołom i znajomym - najpóźniej przed przesiedleniem do gett. Uczynili tak m.in. znani antykwariusze - Abraham Stieglitz w Krakowie i Abe Guntajer w Warszawie.

Trzeba też pamiętać o dziełach znajdujących się w posiadaniu ich twórców - licznych artystów żydowskich oraz ich stowarzyszeń, na czele z istniejącym od $1923 \mathrm{r}$. Żydowskim Towarzystwem Krzewienia Sztuk Pięknych, którego filie znajdowały się w Warszawie, Krakowie, Lwowie, Radomiu, Wilnie, Łodzi i Katowicach ${ }^{14}$.

\section{Lata wojny 1939-1945}

Jak wiadomo, naziści podczas wojny w najmniejszym stopniu nie stosowali się w Polsce do obowiązujących Rzeszę Niemiecką ustaleń Konwencji Haskiej z 1907 r. o prawach i zwyczajach wojny lądowej, gwarantujących nietykalność i ochronę prywatnej własności oraz dóbr kultury. Najeźdźcy brutalnie niszczyli i plądrowali zabytki, świątynie, budynki i pomniki; konfiskowali i rabowali wartościowe przedmioty i skarby kultury, bez względu na to, czy była to własność publiczna czy prywatna. W przypadku tej ostatniej, w pierwszych kilkunastu tygodniach okupacji, obok masowego niszczenia synagog, łupem Niemców padało nagminnie mienie uznane przez nich za bezpańskie (herrenlos). Wśród tysięcy uciekinierów, którzy opuszczali w pośpiechu swoje domy, kierując się do Lwowa i Wilna, znalazło się bardzo wielu przedstawicieli żydowskiej inteligencji znanych z antyhitlerowskich poglądów oraz obawiających się represji z powodu pochodzenia. Siedziby zasob-

12 J. Miliszkiewicz, Tropiciele i miłośnicy poloników, „Rzeczpospolita”, 1 VII 2008, nr 152, s. 14.

${ }^{13}$ Zob. wypowiedź Michała Walickiego, przedwojennego kustosza muzeum, który pracował tam również w czasie okupacji w: Straty kulturalne Warszawy, red. W. Tomkiewicz, Warszawa 1948, s. 139. Można sądzić, że podobne przypadki miały miejsce także w innych muzeach i miastach.

${ }^{14}$ The Black Book of Polish Jewry..., s. 312; zob. też J. Malinowski, Malarstwo i rzeźba Żydów polskich w XIX i XX wieku, Warszawa 2000. 
niejszych spośród nich w pierwszej kolejności zostały obrabowane przez najeźdźców.

Okupowana przez Niemców Polska została w październiku 1939 r. podzielona dekretem Hitlera na tzw. tereny przyłączone do Rzeszy (eingegliederte Ostgebiete) i Generalne Gubernatorstwo (Generalgouvernement, GG). Na „ziemiach wcielonych” znalazło się co najmniej 700 tys. Żydów: w okręgu Kraj Warty z Poznaniem i Łodzią - ponad 435 tys.; w Okręgu Gdańsk-Prusy Zachodnie ponad 30 tys; w Rejencji Katowickiej (przyłączonej do okręgu Śląsk) - ok. 120 tysięcy, w Rejencji Ciechanowskiej z Płockiem (przyłączonej do okręgu Prusy Wschodnie) - ok. 100 tys. Ponad półtoramilionowa społeczność żydowska znalazła się w Generalnej Guberni, podzielonej na cztery dystrykty: krakowski, lubelski, radomski i warszawski. Po wybuchu wojny z ZSRR w czerwcu 1941 r. do GG przyłączono dystrykt Galicja ze Lwowem i ponad półmilionową ludnością żydowską. Utworzono też okręg Białystok z ponad 155 tys. Żydów. W stworzonym w końcu 1941 r. Komisariacie Rzeszy Wschód (Reichskommissariat Ostland) było kilkaset tysięcy Żydów z części wschodnich terytoriów przedwojennej RP, teraz należących do tzw. generalnych okręgów (Generalbezirk) Litwy i Białorusi.

Heinrich Himmler, szef policji i aparatu bezpieczeństwa Rzeszy, przewodniczący tzw. Wspólnoty badawczo-edukacyjnej - Dziedzictwo Przodków (Forschungund Lehrgemeinschaft - das Ahnenerbe), a od początku października 1939 r. Komisarz Rzeszy ds. Umocnienia Niemczyzny (Reichskommissar für die Festigung deutschen Volkstums) utworzył specjalną grupę operacyjną SS, znaną od nazwiska jej dowódcy jako Einsatzkommando Paulsen. Jej celem było, wedle hitlerowskiej nowomowy, „zabezpieczenie niemieckich zabytków sztuki i kultury” (Sicherstellung der Deutschen Kunst- und Kulturhistorischen Denkmälern) na terenie całej okupowanej Polski, czyli faktycznie grabież wszelkich uznanych za wartościowe dóbr kultury. Grupa ta rozpoczęła swoją działalność 23 września 1939 r. i prowadziła ją przez kilkanaście tygodni. Równolegle z nią na terenie Warszawy działali też wysłannicy berlińskiego ministerstwa spraw zagranicznych ze specjalnej komórki kierowanej przez Eberharda von Künsberga, zainteresowani głównie konfiskatą dokumentacji politycznej i wojskowej oraz archiwów.

Z kolei Hermann Göring jako Pełnomocnik Rzeszy ds. Planu Czteroletniego mianował 9 października Kajetana Mühlmanna Specjalnym Komisarzem d.s. Zabezpieczania Dzieł Sztuki na Terenie GG (Sonderbeauftragter für die Erfassung und Sicherung der Kunst- und Kulturschätze im Generalgouvernement). Zgodnie z wydanymi wówczas przepisami dotyczącymi „zabezpieczania zabytków kulturowohistorycznych w Polsce” (Schutzmaßnahmen für kulturgeschichtliche Denkmäler in Polen) majątek osób prywatnych i instytucji uznanych za wrogie Rzeszy Niemieckiej podlegał konfiskacie.

Dziesięć dni później, 19 października, Göring utworzył Główny Urząd Powierniczy - Wschód (Haupttreuhandstelle-Ost, HTO) z siedzibą w Berlinie, będący instrumentem grabieży na terytorium wcielonym do Rzeszy. HTO miał trzy oddziały regionalne: w Poznaniu (Posen) z filią w Łodzi (od 1940 r. Litzmannstadt) dla Kraju 
Warty, w Gdańsku (Danzig) obejmujący Pomorze oraz w Katowicach (Kattowitz) dla Górnego Śląska. HTO zajmował się spisem i konfiskatą majątku nieruchomego i ruchomego zarówno Polaków, jak i Żydów, zarządzaniem zagrabionym mieniem, jego wykorzystaniem i sprzedażą ${ }^{15}$. Od 1 grudnia 1939 r. HTO został upoważniony do konfiskat dzieł sztuki i wszelkich dóbr kultury. W tym celu Himmler powołał wówczas Urząd Generalnego Powiernika dla zabezpieczenia niemieckich dóbr kultury na Wschodnich Ziemiach Przyłączonych (Generaltreuhänder für die Sicherstellung deutschen Kulturgutes in den eingegliederten Ostgebieten). Na jego czele stał prof. Heinrich Harmjanz, wysoki funkcjonariusz SS z Ahnenerbe. Urząd ten działał w ścisłej współpracy z policją bezpieczeństwa.

15 listopada 1939 r. Gubernator Generalny Hans Frank utworzył odrębny Urząd Powierniczy GG i wydał rozporządzenie o konfiskacie całego mienia byłego państwa polskiego na tym terenie. Miesiąc później, 16 grudnia, uzupełnił je zarządzeniem o konfiskacie dzieł sztuki i dóbr kultury należących do Kościoła i osób prywatnych, uznanych za „dobra w publicznym posiadaniu” (öffentlicher Besitz) ${ }^{16}$. Biuro Mühlmanna, podporządkowane tymczasem Frankowi, podjęło prowadzoną na szeroką skalę akcję zaboru wszelkich wartościowych obiektów sztuki i kultury.

24 stycznia 1939 r. ogłoszony został w GG pakiet rozporządzeń uprawniających niemiecką administrację, policję bezpieczeństwa i Wehrmacht do przejmowania żydowskiej i polskiej własności prywatnej. Zgodnie z nim zalegalizowano także wcześniejsze rabunki. Wobec Żydów wprowadzono nadto obowiązek pisemnego zgłoszenia do marca 1940 r. całego posiadanego majątku. Jeśli po tej dacie znaleziono u nich niezgłoszone wartościowe przedmioty, traktowano je jako „bezpańskie” i automatycznie konfiskowano, a ich właściciel podlegał karze więzienia. Warto przy tym podkreślić, że wprowadzone ponad miesiąc wcześniej przez Mühlmanna rozporządzenie o zgłaszaniu zabytków ruchomych, obowiązujące obywateli polskich bez względu na pochodzenie, było powszechnie ignorowane jako nieobwarowane karami i pozbawione egzekutywy. Styczniowe natomiast, wymierzone wyłącznie przeciw Żydom, było surowo egzekwowane; połączone z zakazem zmiany miejsca zamieszkania, antycypowało rychłą gettoizację ludności żydowskiej.

„Niearyjskie pochodzenie” implikowało - nie tylko w praktyce, ale i na gruncie wprowadzanych w GG przepisów - całkowitą bezkarność grabieżców, jako że zgłoszone przez Żydów dobra również podlegały konfiskacie, tyle że na mocy innych paragrafów, wzorowanych na obowiązującym w Rzeszy antyżydowskim ustawodawstwie. Wprowadzano je tam stopniowo od chwili przejęcia władzy przez Hitlera

${ }^{15}$ J. Dingell, The Haupttreuhandstelle Ost. The Treuhandstelle Posen and the Expriopriation of Property During World War II, „Studia Historiae Oeconomicae” t. 24, Poznań 2001, s. 111-137; zob. też B. Rosenkötter, Treuhandpolitik. Die „Haupttreuhandstelle Ost” und der Raub polnischer Vermögen 1939-1945, Essen 2003.

${ }^{16}$ Dzięki tej celowo niejasnej i szerokiej kategorii Niemcy mogli „legalnie” konfiskować wszystko, co chcieli ukraść. Zob. § 2 i § 3 rozporządzenia dla GG z 16 XII 1939 [w:] Walka o dobra kultury. Warszawa 1939-1945, red. S. Lorentz, Warszawa 1970, t. 2, s. 416-417. 
w 1933 r., a od 1938 r. - po Anschlussie Austrii i pogromach „nocy kryształowej” coraz intensywniej i okrutniej, aż w końcu stało się ono integralnym elementem „ostatecznego rozwiązania kwestii żydowskiej” (Endlösung der Judenfrage).

W tym kontekście wypadnie zwrócić uwagę na odmienne deficyty w potocznej wiedzy o hitlerowskiej grabieży dóbr kultury występujące na Zachodzie Europy i w USA z jednej, a w Polsce i państwach b. ZSRR z drugiej strony. Na Zachodzie często zapoznaje się fakt, że w odróżnieniu od Rzeszy Niemieckiej oraz okupowanych państw Europy Zachodniej i Środkowej (włącznie z Czechosłowacją i Węgrami), w Polsce - a od lata 1941 r. także na wschodzie Europy - Niemcy rozmyślnie niszczyli i grabili nie tylko własność żydowską i mienie osób uznanych za „wrogów państwa i narodu niemieckiego”, ale też własność państwową, samorządową, a nierzadko również kościelną i prywatne mienie „etnicznych” Polaków. W Kraju Warty prześladowania majątkowe stosowane wobec Kościoła katolickiego i ludności polskiej były nawet porównywalne ze stosunkiem nazistów do własnosci żydowskiej. Represje te miały cel nie tylko ekonomiczny, ale też ideologiczny. Niszczenie kultury polskiej, wymordowanie polskiej inteligencji (nauczycieli, księży, przedstawicieli wolnych zawodów itd.) oraz przymusowe wysiedlenia dużych grup ludności polskiej, zazwyczaj połączone z prawem brania jedynie bagażu podręcznego, miały na celu zniewolenie Polaków i sprowadzenie ich do roli taniej siły roboczej, pomocnej w realizacji nazistowskiej wizji przestrzeni życiowej dla Herrenvolku ${ }^{17}$.

Bez względu jednak na to, jak bardzo społeczeństwo polskie i poszczególne jego warstwy były eksploatowane i represjonowane, nie miało to charakteru totalnego wywłaszczania całej społeczności, przygotowującego jej eksterminację - jak w przypadku obywateli narodowości żydowskiej. Ta wiedza z kolei w opinii obiegowej w Polsce ciągle jest mało obecna, podobnie jak u wszystkich naszych wschodnich sąsiadów.

Tymczasem Żydzi, wraz ze swoim mieniem, znaleźli się w znacznie gorszej sytuacji niż większość Polaków jeszcze przed przymusowymi przenosinami do gett. Wobec powszechnych i jawnych zniszczeń i rabunków, dokonywanych w pierwszych tygodniach wojny i okupacji przez Wehrmacht i jednostki specjalne SS, byli zupełnie bezbronni. Tak samo jak później, gdy zaczęła się zorganizowana urzędowa grabież połączona z kradzieżą i wymuszeniami, których na własną rękę dopuszczali się funkcjonariusze niemieckiego aparatu władzy i policji. Stanowiący większość ludności żydowskiej ortodoksi, a także uciekinierzy i przesiedleńcy z innych regionów czy miast przeważnie nie mogli także liczyć na pomoc Polaków, z którymi zwyczajowo nie mieli kontaktów i ze strony których groził im agresywny

${ }^{17}$ Terminem „Polacy” określam nieżydowskich obywateli Polski, których naziści zaliczali do tzw. aryjczyków. Trzeba dodać, że na terenach przyłączonych do Rzeszy ogólna sytuacja Polaków była bez porównania gorsza niż w GG. W 1940 r. wysiedlono do GG setki tysięcy Polaków i Żydów z Kraju Warty, który w ciągu dziesięciu lat miał zostać całkowicie zgermanizowany. Uchodźcy mogli zabrać ze sobą jedynie rzeczy pierwszej potrzeby. Zabieranie jakichkolwiek cennych przedmiotów było surowo zabronione. 
antysemityzm. Ci, którzy mieli wśród Polaków przyjaciół i znajomych, starali się przed wysiedleniem do gett deponować po tzw. „stronie aryjskiej” choćby część swojego mienia, zwłaszcza przedmioty wartościowe. Zachowało się wiele gorzkich świadectw mówiących, że Polacy często zawłaszczali powierzone im w zaufaniu dobra, i to jeszcze za życia ich właścicieli lub w sytuacjach, gdy ważył się ich los. Niezależnie od tej haniebnej praktyki, wiele cennych rzeczy - w tym dzieła sztuki i rzemiosła - Żydzi zmuszeni byli wymieniać, sprzedawać za bezcen albo wykupywać się nimi z rąk szmalcownikow i szantażystów, próbując przeżyć po jednej lub drugiej stronie muru.

Trudno ocenić, jaka część zasobów gmin wyznaniowych i różnych organizacji żydowskich oraz prywatnej własności polskich Żydów, w szczególności zabytków ruchomych, obiektów rytualnych, dzieł sztuki i wyrobów rzemiosła została całkowicie zniszczona, a jaką część Niemcy zagrabili i wywieźli urzędowo lub pokątnie do tzw. Wielkiej Rzeszy, tj. na teren Niemiec, Austrii i Protektoratu Czech i Moraw. Udokumentowany mechanizm i skala nazistowskiej grabieży nie pozostawia jednak wątpliwości, że była to przeważająca większość ruchomego mienia żydowskiej społeczności Polski przedwojennej.

Proces ten rozpoczął się w 1939 r. wraz z pierwszymi zniszczeniami dokonanymi podczas Blitzkriegu; zbombardowano wtedy np. okolice ulicy Świętokrzyskiej w Warszawie, w wyniku czego spłonęły znajdujące się tam znane żydowskie księgarnie, antykwariaty i galerie sztuki. Historyk Emanuel Ringelblum, późniejszy twórca podziemnego archiwum getta warszawskiego, notował w dzienniku pod datą 5-8 grudnia 1939 r.: „Co stracono w dziedzinie nauki żydowskiej w Warszawie? Archiwum na Jezuickiej, dzieje gospodarcze, historia przemysłu. Archiwum ministerstwa Oświaty, cenzura, szkolnictwo. Wszystkie obrazy Weinlesa, rękopisy Trunka. Rozniósł je wiatr na wszystkie strony świata"18.

Zbiory Głównej Biblioteki Judaistycznej, wraz z częścią biblioteki im. Borochowa zostały w końcu 1939 r. wywiezione z Warszawy przez Kommando Paulsen do siedziby Głównego Urzędu Bezpieczeństwa Rzeszy (Reichssicherheitshauptamt, RSHA) w Berlinie, gdzie „policja bezpieczeństwa miała wykorzystać je jak najlepiej do walki z żydostwem"19.

Na terenach podbitych Wehrmacht i specjalne jednostki SS zniszczyły setki synagog i bóżnic, podpalając lub wysadzając je w powietrze wraz ze zwojami Tory, księgami rabinicznymi i przedmiotami liturgicznymi. Z upodobaniem przeprowadzano te niszczycielskie akcje podczas szabatu lub żydowskich świąt, łączono je ze znęcaniem się i zabójstwami religijnych Żydów. Nierzadko też nakładano wysokie kontrybucje na dotknięte tymi zbrodniczymi postępowaniami gminy

${ }^{18}$ E. Ringelblum, Kronika getta warszawskiego, Warszawa 1983, s. 36.

${ }^{19}$ A. Mężyński, Die judaistische Bibliothek bei der Großen Synagoge in Warschau und das Schicksal der Bücher aus dem Warschauer Ghetto [w:] Jüdischer Buchbesitz als Raubgut, red. R. Dehnel, Frankfurt am Main 2006, s. 91. 
żydowskie, które spłacały je częściowo w naturze, czyli precjozami i cennymi obiektami ${ }^{20}$.

28 marca 1941 r. gazeta „Frankfurter Zeitung” z dumą donosiła o spaleniu słynnej Jesziwy Mędrców Lublina wraz z jej biblioteką: „Byliśmy szczególnie dumni ze zniszczenia Akademii Talmudycznej [...] uchodzącej za najważniejszą w Polsce. [...] Wyrzuciliśmy z budynku wszystkie zbiory wielkiej biblioteki talmudycznej, zanieśliśmy je na rynek, a następnie podpaliliśmy. Płomień zgasł dopiero po dwudziestu godzinach. Lubelscy Żydzi zebrali się dookoła ognia i gorzko łkali. Ich płacz niemal nas zagłuszył. Wezwaliśmy orkiestrę wojskową, której muzyka wraz z okrzykami żołnierzy ostatecznie stłumiła odgłosy żydowskiego płaczu"21.

Część ocalonych zbiorów owej biblioteki (ok. 23 tys. tomów) przeniesiono do biblioteki publicznej im. Łopacińskich, służącej w Lublinie za magazyn skonfiskowanych książek, które zgodnie z dyrektywami HTO i RSHA mogły okazać się przydatne w tzw. „studiach żydowskich” uprawianych przez nazistów z perwersyjnym upodobaniem ${ }^{22}$. Pozostałe książki, uznane za bezwartościowe, a nieraz całe biblioteki, wysyłano masowo na przemiał. Taki los spotkał przykładowo prawie wszystkie biblioteki należące do Żydowskiego Stowarzyszenia Kulturalno-Oświatowego Tarbut (Kultura). W Krakowie jeszcze przed utworzeniem getta wszystkie czytelnie, wypożyczalnie, antykwariaty i księgarnie żydowskie przejął likwidator, odsyłając większość ich zasobów na makulaturę, a nawet paląc je na miejscu ${ }^{23}$.

W nowym budynku krakowskiej Biblioteki Jagiellońskiej urządzono główny magazyn skonfiskowanych w GG dóbr kultury. Znalazły się tu wyselekcjonowane księgozbiory rozwiązanych żydowskich stowarzyszeń i organizacji, m.in. połowa wcześniej wspomnianej Biblioteki Ezra. Także tutaj składowano zrabowane judaika i prywatne biblioteki żydowskich uczonych i rabinów, m.in. słynnego cadyka z Bobowej ${ }^{24}$. Część z nich przekazano do założonego w Krakowie w kwietniu 1940 r. Instytutu Niemieckiej Pracy Wschodniej (Institut für Deutsche Ostarbeit), gdzie trafiały też bezpośrednio. Przykładem może tu być warszawska biblioteka Samuela Adalberga, wybitnego znawcy folkloru żydowskiego i polskiego, który w listopadzie 1939 r. popełnił samobójstwo. Została ona zagrabiona, jak wspomina Ringelblum, przez Petera-Heinza Seraphima, hitlerowskiego „eksperta” do spraw tzw. Żydów Wschodnich (Ostjuden). Od początku okupacji do końca 1940 r. Seraphim

${ }^{20}$ J. Borin, op. cit., s. 447. Porównaj np. z Ch. Estreicher, op. cit.; B. Bieńkowska, op. cit.

${ }^{21} \mathrm{~J}$. Borin, op. cit., s. 447-448.

${ }^{22}$ B. Bieńkowska, op. cit., s. 167.

${ }^{23} \mathrm{Z}$ kwerendy archiwalnej do przygotowywanego przeze mnie opracowania dotyczącego żydowskich antykwariatów i handlu sztuką w okresie okupacji.

${ }^{24}$ B. Bieńkowska, op. cit., s. 128-129. Zob. też E. Kuntze, Dzieje Biblioteki Jagiellońskiej pod okupacja niemiecka w okresie od 1 września 1939 do 18 stycznia 1945 r. [w:] Biblioteki Naukowe w Generalnym Gubernatorstwie w latach 1939-1945. Wybór dokumentów źródtowych, red. A. Mężyński, H. Łaskarzewska, Warszawa 2003, s. 286-287. 
przebywał w Krakowie jako specjalny doradca rządu GG i orędownik stworzenia wspomnianego instytutu ${ }^{25}$.

W Kraju Warty publiczne i prywatne, żydowskie i polskie księgozbiory zwożono do Poznania i składowano w zamienionym na gigantyczny magazyn kościele świętego Michała Archanioła. Wyselekcjonowane spośród nich cymelia i rzadkie publikacje trafiały do centrali HTO i RSHA w Berlinie albo do nowo powstałych w tym Mustergau - „wzorcowym kraju” Rzeszy - instytucji niemieckich, jak poznański Uniwersytet Rzeszy (Reichsuniversität) ${ }^{26}$ czy istniejąca przez krótki czas łódzka filia frankfurckiego Instytutu ds. Badania Kwestii Żydowskiej (Institut zur Erforschung der Judenfrage).

Frankfurcki instytut powstał z inicjatywy głównego ideologa NSDAP, Alfreda Rosenberga, jako część planowanej wyższej szkoły elity nazistowskiej (Hohe Schule). On także utworzył specjalną jednostkę znaną jako Einsatzstab Reichsleiter Rosenberg (ERR), która miała „zabezpieczać materiały naukowe” przyszłej placówki, a w istocie była kolejną instytucją zajmującą się grabieżą dóbr kultury. ERR próbował bez powodzenia rozwinąć swoją aktywność w GG, z niewiele lepszym skutkiem w Kraju Warty, za to po sukcesach w obrabowywaniu francuskich Żydów zmierzał do zmonopolizowania rabunku żydowskiego mienia kulturalnego na podbitych terenach ZSRR, korzystając z nowej funkcji Rosenberga, który w lipcu 1941 r. został mianowany ministrem Rzeszy dla okupowanych terenów wschodnich (Reichsminister für die besetzten Ostgebiete).

Książki, które znalazły się w gettach, spotkał jeszcze gorszy los. Księgi religijne, otaczane szczególną czcią przez ortodoksyjnych Żydów, niekiedy cudem uratowane podczas przesiedleń, wielu z nich spaliło w gettach z obawy przed profanacją ${ }^{27}$. Najczęściej jednak wyprzedawano je na ulicach obok najróżniejszych książek w jidysz, hebrajskim, polskim, niemieckim i w innych językach ${ }^{28}$. Zdarzało się także, że z braku opału książkami palono w piecach.

Szacuje się, że po upadku powstania w getcie warszawskim w 1943 r. w ruinach zniszczonej dzielnicy żydowskiej pozostało ok. pół miliona osieroconych tomów. Wilhelm Witte, niemiecki dyrektor Biblioteki Państwowej w Warszawie (Staatsbibliothek Warschau), gromadzącej najważniejsze przedwojenne biblioteki naukowe stolicy - i rzecz jasna zamkniętej dla Polaków - na próżno zabiegał o pozwolenie zebrania książek porozrzucanych w ruinach getta i umieszczenia ich w dość dobrze zachowanym budynku Biblioteki Judaistycznej obok wysadzonej w powietrze w maju 1943 r. Wielkiej Synagogi na Tłomackiem² ${ }^{29}$. Wcześniej, w latach 1940-1942, Wittemu udało się uzyskać pewną liczbę książek skonfiskowanych z księgarń i bibliotek żydowskich, jak również z opuszczonych mieszkań prywatnych znajdu-

\footnotetext{
${ }^{25}$ E. Ringelblum, op. cit., s. 234.

${ }^{26}$ Według „Frankfurter Zeitung” z 7 III 1941 r. było to 400 tys. tomów; za: The Black Book of Polish Jewry..., s. 300.

${ }^{27}$ E. Ringelblum, op. cit., s. 108 i 186.

${ }^{28}$ Ibidem, s. 353.

${ }^{29}$ A. Mężyński, op. cit., s. 92-93.
} 
jących się poza gettem ${ }^{30}$. Utworzył z nich w Staatsbibliothek Warschau specjalny dział książek „zabezpieczonych”31.

Wraz z likwidacją gett bezdomne książki uległy zniszczeniu, zostały pogrzebane w ruinach lub popadły w poniewierkę.

Podobny los stał się udziałem przedmiotów kultu synagogalnego i rytuału domowego, tradycyjnie wyrabianych ze srebra ${ }^{32}$. Gromadzono je i selekcjonowano wraz z innymi obiektami wykonanymi z metali szlachetnych w powołanych do tego urzędowych komórkach podległych administracji gett, powiatów i dystryktów, Urzędom Powierniczym, a także konkurującemu z nimi aparatowi policji bezpieczeństwa, podporządkowanemu berlińskiej centrali.

Przedmioty zabytkowe albo wartościowe ze względu na materiał kierowano najpierw do lokalnych składów. W Toruniu i w Łodzi mieściły się one w miejskich muzeach, w Lublinie - na zamku, w Krakowie - w Bibliotece Jagiellońskiej, w Warszawie - w pasażach Simonsa i Luksemburga ${ }^{33}$, a obiekty artystyczne - w Muzeum Narodowym, które podczas okupacji przemianowano na Muzeum Miejskie (Stadtmuseum) i zamknięto dla zwiedzających ${ }^{34}$. Stamtąd judaika, wraz ze zrabowanymi Żydom precjozami i wyrobami z metali szlachetnych, wywożono zazwyczaj do Berlina, gdzie były poddawane kolejnej selekcji, po której przekazywano je wybranym instytucjom, sprzedawano w Lombardzie Miejskim (Städtische Pfandleihe) bądź przetapiano $^{35}$.

W końcu 1939 r. Kommando Paulsen wywiozło z Warszawy do Berlina również judaika ze wspomnianego wcześniej Muzeum Bersohna oraz niewielki ich zbiór zgromadzony przed wojną przez Muzeum Narodowe ${ }^{36}$. W Łodzi, w drugiej połowie

${ }^{30}$ Staatsbibliothek Warschau wybrała kilka tysięcy tomów z żydowskich książek zgromadzonych w Pasażu Simonsa i Luksemburga. Pozostałe żydowskie książki zabrano bezpośrednio z mieszkań opuszczonych przez wysiedlanych Żydów. Było to jedno z najsmutniejszych zadań, które pod nadzorem policji musieli wykonywać polscy pracownicy biblioteki. Zob. E. Assbury, Losy księgozbiorów warszawskich zabezpieczonych w BN w latach 1940-1944 [w:] Walka o dobra kultury. Warszawa 1939-1945, t. 1, s. 267 n.

${ }^{31}$ Ibidem, s. 266-269.

${ }^{32}$ Pracuję obecnie nad obszerniejszym studium poświęconym dziejom polskich judaików i ich zbiorów aż do dnia dzisiejszego.

${ }^{33}$ Ch. Estreicher, op. cit, s. 403 [wyd. polskie s. 452].

${ }^{34}$ Zob. M. Sieramska, Z problematyki wojennych strat żydowskiej sztuki kultowej, „Cenne Bezcenne Utracone” Nr 2 (14) kwiecień 1999, s. 8; z e-maila przesłanego do autorki przez obecną archiwistkę warszawskiego Muzeum Narodowego p. Lidię Karecką wynika, że w archiwach Muzeum odnotowano jeden przypadek przekazania zbioru osiemdziesięciu pięciu judaików i hebrajskich książek (miało to miejsce 27 I 1943 r.).

${ }^{35}$ Uzyskaną ze sprzedaży kwotę, pomniejszoną o 10 proc. prowizji lombardu, wysyłano do HTO. Zob. N. Szuman, Grabież dóbr kultury polskiej w ramach działalności „Generalnego Powiernika dla zabezpieczenia niemieckich dóbr kultury na wschodnich terenach przyłaczonych", „Biuletyn Głównej Komisji Badania Zbrodni Hitlerowskich” kwiecień 1948 r., s. 200-201.

${ }^{36}$ Informacje o trzystu judaikach Muzeum Narodowego zob. Straty kulturalne Warsza$w y$, s. 184-185. Podana tam liczba dotyczy prawdopodobnie zbiorów muzeum Bersohna, przewiezionych przez Niemców do gmachu MN, i własnych judaików MN, których było 
1940 r., po wypędzeniu z dotychczasowych siedzib i zamknięciu w getcie wielotysięcznej rzeszy tamtejszej społeczności żydowskiej, naziści zdołali zgromadzić tak wielką ilość przeróżnych wartościowych dóbr, że sprzedawali je na miejscu Niemcom i folksdojczom, nie nadążając z ich wysyłką do Poznania i Berlina ${ }^{37}$.

Gdy w 1942 i 1943 r. w ramach tzw. Akcji Reinhardt masowo deportowano polskich Żydów do obozów zagłady, w opustoszałych gettach brygady utworzone z ostatnich niedobitków zmuszano do wyszukiwania ukrytych kosztowności i ich selekcjonowania. Formalnie wszystko przechodziło na własność skarbu GG lub Rzeszy. W praktyce, wraz z coraz większą ilością pozostałego po zamordowanych mienia i potęgującą się korupcją w hitlerowskich szeregach, zjawiskiem powszechnym stał się rozdział znacznej części atrakcyjnych łupów pomiędzy bezpośrednich wykonawców Zagłady z jednostek SS i gestapo, ich przełożonych w GG i Berlinie, jak też administrację cywilną różnego szczebla. Towarzyszył temu rozkwit czarnego rynku, obsługującego głównie miejscowych Niemców i folksdojczów, choć resztki dostawały się także polskiej ludności, która zresztą na własną rękę penetrowała tereny wyludnionych gett w poszukiwaniu zdobyczy.

Po wywózce na śmierć w Bełżcu 25 tys. Żydów z getta rzeszowskiego polski dyrektor tamtejszego niewielkiego muzeum miejskiego, który uzyskał pozwolenie na wejście do magazynów ze zrabowanymi przedmiotami, zapisał w swoim dzienniku 28 listopada 1942 r.: „[C] o było ciekawego, dawno już wywieziono w świat, pozostał szmelc, w dodatku tak zwalony, tak poniszczony, że trudno jest cokolwiek znaleźć. Dziwni są ci Niemcy: z jednej strony pracowici, oszczędni, szanujący rzeczy. Ale gdy chodzi o stosunek do rzeczy pożydowskich - ogarnął ich demon zniszczenia. Co się rzeczy poniszczyło, to strach pomyśleć. Znane jest zamiłowanie Żydów do srebra, mieli go mnóstwo, również antycznych przedmiotów. Wszystko to połamano i wywieziono na przetopienie. Skandal. A co zniszczono mebli, obrazów!”38.

W jednym z łódzkich archiwów zachowały się fragmenty dwóch rejestrów obrazów skonfiskowanych podczas wysiedleń do getta trwających do maja $1940 \mathrm{r}^{39}$ Listy te opiewają na 4264 i 10333 przedmiotów ${ }^{40}$. Nie umieszczono w tych spisach, rzecz jasna, nazwisk ograbionych właścicieli, za to wprowadzono rubrykę

ok. 70 sztuk. Zob. E. Martyna, Judaica w zbiorach Muzeum Narodowego w Warszawie, Warszawa 1993.

${ }^{37}$ N. Szuman, op. cit., s. 217-218.

${ }^{38}$ F. Kotula, Diariusz muzealny, Rzeszów 1999, s. 31.

${ }^{39}$ Żydzi mogli zabrać do getta jedynie kilka przedmiotów pierwszej potrzeby. Ich majątek ruchomy, głównie złoto i biżuteria, odsyłano do Berlina. Jak podaje rejestr z 16 VII 1940 r., w getcie łódzkim mieszkało wtedy 160 tys. ludzi. Wszystkie przedmioty należące do Żydów zagrabione po 1 V 1940 r., zgodnie z rozporządzeniem z 23 X 1940 r., musiały zostać natychmiast odesłane do Zarządu Getta (Ghetto Verwaltung), na którego czele stał Hans Biebow. 16 III 1942 r. zarząd ów wszedł w skład HTO. Pod koniec 1942 r. rozporządzenie to objęło cały majątek ruchomy ze wszystkich likwidowanych gett w Kraju Warty. Zob. Tonaca Łódź (lata 1939-1945) / Das sinkende Boot (der Zeitraum 1939-1945), red. K. Radziszewska, Łódź 2002, s. 56-59.

${ }^{40}$ Archiwum Muzeum Sztuki w Łodzi (bez sygnatur). 
z klasyfikacją skonfiskowanych obiektów. Museumswürdig klasyfikowało obraz jako obiekt rangi muzealnej. MJ oznaczało Malerei Jüdisch, czyli malarstwo żydowskie, EK - Entartete Kunst, czyli sztukę zdegenerowaną. V - Verwendet: verliehen albo verkauft wskazywało, że dany obiekt został zagospodarowany: wypożyczony lub sprzedany. Naniesione uzyskane ceny to zazwyczaj kilka reichsmarek. Wśród wymienionych z nazwiska autorów skonfiskowanych obrazów znaleźli się cenieni polscy i żydowscy artyści ${ }^{41}$.

W stolicy GG Krakowie odbyło się co najmniej kilka aukcji wartościowych polskich obrazów skonfiskowanych tamtejszym żydowskim kolekcjonerom ${ }^{42}$. Zaś po zlikwidowaniu w 1943 r. tamtejszego getta „oddzielnie grupy więźniów obchodziły mieszkania w poszukiwaniu obrazów. Dzieła malarzy żydowskich, bez względu na temat, palono od razu [na podwórzu przy ul. Józefińskiej 16], tak samo niszczono obrazy malarzy polskich i obcych o tematyce żydowskiej. Do oceny zrabowanych obrazów powołali Niemcy rzeczoznawcę. Okazy cenniejsze odsyłano do zbiorów niemieckich, mniej cenne sprzedawała straż obozowa, pilnująca Żydów przy pracy, ludziom, którzy podchodzili w nadziei nabycia rzeczy za bezcen”43.

Gdy w warszawskim getcie w lipcu 1942 r. zaczęła się wielka akcja wysiedleńcza, w budynku przy ulicy Stawki niedaleko Umschlagplatzu, w którym do wojny mieściła się szkoła fotograficzna, Niemcy umieścili tzw. Werterfassung. Ta komórka organizacyjna zajmowała się szacowaniem zagrabionego Żydom mienia i jego wywozem do Rzeszy. Niemcy skoszarowali tam kilkuset Żydów, którzy wykonywali zlecone im prace. Jeden z nich, który ocalał, wspominał: „Niemcy powiedzieli nam, że będą zwożone różne przedmioty z opuszczonych mieszkań do renowacji. Zapytali, co kto umie robić. Powiedziałem, że jestem konserwatorem obrazów. Kazano mi zorganizować pracownię zajmującą się konserwacją obrazów. Wraz z kilkunastu osobami przecierałem olejem te obrazy i one zaczynały ożywać. Niemcy byli zachwyceni. Czasami cerowałem, robiłem ramy. Ta praca trwała dość długo, bo pamiętam samochody, które stale przyjeżdżały z obrazami, nieraz bardzo cennymi" ${ }^{44}$.

„Z konieczności tymczasowo anonimowi” autorzy książki The Nazi Kultur in Poland („Nazistowska »Kultur« w Polsce”) - opublikowanej w Londynie w 1945 r., ale napisanej i przetłumaczonej na angielski w konspiracji trzy lata wcześniej stwierdzali, że dokonywane w Warszawie „konfiskaty kolekcji należących do osób pochodzenia żydowskiego” to problem tak rozległy, iż „wymagałby osobnego roz-

${ }^{41}$ Według berlińskiego raportu Hermjanza i Sieversa z 28 X 1940 r. chodziło o 3530 obrazów, zob. N. Szuman, op. cit., s. 195; resztę stanowiły zapewne głównie sztychy i oleodruki.

${ }^{42}$ O jednej z nich, która odbyła się pod koniec 1940 r., pisze Estreicher, op. cit., s. 55 [wyd. polskie s. 104].

${ }^{43}$ D. Agatstein-Dormontowa, Żydzi w Krakowie w okresie okupacji niemieckiej [w:] Kraków w latach okupacji 1939-1945, „Rocznik Krakowski” t. XXXI, Kraków 1949-1957, s. 221.

${ }^{44}$ Autor wspomienia, pan J.B.D. był zatrudniony w Werterfassung do kwietnia $1943 \mathrm{r}$. Jego relacja [w:] S. Chaskielewicz, Ukrywałem się w Warszawie. Styczeń 1943 - styczeń 1945, Kraków 1988, s. 119. 
działu”45 . Skonfiskowane dzieła sztuki przechowywano najczęściej w budynku Muzeum Narodowego przemianowanym na Stadtmuseum Warschau. I tak zagrabiona przez nazistów kolekcja Rotwanda spoczęła obok zbiorów ukrytych tam wcześniej przez żydowskich właścicieli ${ }^{46}$. Cenniejsze dzieła z tych zbiorów zostały wywiezione do Rzeszy. Inne prywatne kolekcje warszawskie, m.in. Kronenberga, Natansona, Meyera i Reichera, uległy zniszczeniu podczas bombardowań miasta, spłonęły w Powstaniu Warszawskim lub zostały rozkradzione ${ }^{47}$.

Podobny los spotkał zasoby żydowskich galerii sztuki i antykwariatów artystycznych. Już w 1939 r. zamknięto je lub poddano tzw. „aryzacji”: na przykład holenderski nazista Hans Peter Menten przejął w zarząd komisaryczny (komissarische Treuhand) najbardziej znany krakowski antykwariat Abrahama Stieglitza na Rynku Głównym i jeszcze trzy inne, których właścicielami byli Żydzi ${ }^{48}$. Warszawskie antykwariaty należące do Żydów zwykle ulegały likwidacji, jak salony Abego i Bernarda Gutnajerów. Kilka innych, np. Dom Sztuki czy Antykwariat Artystyczny, przeszło na własność ich polskich pracowników. Ich prawowici właściciele albo zdołali opuścić Polskę przed wybuchem wojny, albo zostali wysiedleni do getta, jak I. Reingewirc z Antykwariatu Artystycznego ${ }^{49}$.

Słabo zbadanym obszarem relacji polsko-żydowskich pod okupacją niemiecką jest kwestia stosunku Polaków do mienia żydowskiego. Jak traktowali dobra pozostawione po „aryjskiej stronie”, gdy ich właścicieli wysiedlono do gett? Jak postępowali, gdy Żydzi musieli za ich pośrednictwem sprzedawać swój majątek, by zapewnić sobie przetrwanie w getcie lub opłacić kryjówki i szantażystów po „aryjskiej stronie”? Wreszcie: co stało się z opuszczonym mieniem „niczyim” po śmierci właścicieli?

Do niedawna pytań takich nie stawiano nie tylko w publicznej debacie w kraju; nie zadawali ich nawet polscy historycy. Szmalcowników i szantażystów uważano powszechnie za zjawisko marginalne. Przez wiele lat pozostawaliśmy głusi na bolesne wspomnienia ocalałych Żydów, którzy skarżyli się, że polscy sąsiedzi, wykorzystując tragiczną sytuację właścicieli, cynicznie przywłaszczali powierzone im dobra. Zarzuty takie traktowano jako przejaw „typowego dla Żydów antypoloni-

${ }^{45}$ The Nazi Kultur in Poland. By several authors of necessity temporarily anonymous. Wirtten in Warsaw under the German Occupation and published for the Polish Ministry of Information by His Majesty's Stationery Office, London 1945, s. 112.

${ }^{46}$ Straty kulturalne Warszawy, s. 139. Według Walickiego nie sporządzono kompletnych rejestrów takich przedmiotów, ibidem, s. 135. To samo dotyczyło zarówno przedmiotów ukrytych przez Żydów w Muzeum na początku wojny, jak i depozytów potajemnie powierzonych tej instytucji.

${ }^{47}$ Ch. Estreicher, op. cit., pod hasłem „Warszawa”. Zob. też K. Sroczyńska, Straty wojenne wdziedzinie nowoczesnego malarstwa irzeźby polskiej, „Zeszyty Naukowe UJ, Opuscula Musealia" 1994 (wersja internetowa: www3.uj.edu.pl/Muzeum/artykuly/straty-wojenne.htm).

${ }^{48}$ Zob. przyp. 89.

${ }^{49}$ S. Bołdok, Antykwariaty artystyczne, salony i domy aukcyjne, Warszawa 2004, s. 312 i 361. 
zmu"; takie opinie słyszy się zresztą do dzisiaj. Po pół wieku milczenia Jan Tomasz Gross, socjolog i historyk, poruszył ów temat tabu w swoich dwóch książkach Sasiedzi (2000) i Strach (opublikowany w USA w 2006, a w Polsce w 2008) ${ }^{50}$. Wywołały one wstrząs i burzliwą ogólnonarodową dyskusję.

Gross dowodzi, że już podczas okupacji spora część polskiej ludności przywłaszczyła sobie mienie opuszczone przez wysiedlanych, deportowanych i mordowanych Żydów, gdy to tylko było możliwe pod bokiem Niemców. Bogacono się, zajmując nagminnie nieruchomości Żydów i ich majątek ruchomy, nieraz z pomocą Polaków ukrywany przed okupantem. Gross podkreśla dwa aspekty tego zjawiska. Po pierwsze, jego zdaniem w procederze tym brały udział przede wszystkim niższe warstwy polskiego społeczeństwa. Po drugie, wartość własności przejętej lub skradzionej przez Polaków była zazwyczaj niewielka, jako że ich żydowscy sąsiedzi byli przeważnie biedni.

Nowe badania, zwłaszcza Jana Grabowskiego, dowodzą, że Gross idealizuje lepiej wykształcone i zamożniejsze warstwy społeczeństwa polskiego ${ }^{51}$. W podejściu do dóbr kultury stanowiących własność prześladowanych Żydów można wyodrębnić kilka kwestii. Jedna - to zdolność oszacowania faktycznej, a nie tylko rzeczowej wartości danych przedmiotów, co wymagało pewnej kompetencji kulturowej. Mówiąc krótko, oparcie się pokusie przywłaszczenia było łatwiejsze w przypadku rzeczy niewielkiej wartości. Gdy chodziło o cenne artefakty, jako usprawiedliwienie i uzasadnienie ich zawłaszczenia uruchamiano nawet motywację narodowo-patriotyczną ${ }^{52}$. Innym ważnym czynnikiem były okoliczności przejęcia cudzej własności. Jawnemu rabunkowi dokonywanemu przez motłoch, tudzież paskarskiemu wykupywaniu dóbr od znajdujących się w sytuacji przymusowej Żydów, praktykowanemu bezwstydnie przez okupacyjnych nowobogackich, przeciwstawiano dyskretne, najchętniej obywające się bez świadków przejmowanie własności przez ludzi z tzw. „towarzystwa”. Gdy korzystali z pośredników, abstrahowali od pochodzenia nabywanych obiektów i oczekiwali zrozumienia dla swojej pasji kolekcjonerskiej. W razie wątpliwości odwoływali się do wspomnianego już pretekstu ratowania substancji narodowej, nie mówiąc o niezawodnym i zazwyczaj niedowodliwym argumencie pomocy żydowskim właścicielom. Naturalnie solidarnie potępiano przy tym przypadki jawnej kolaboracji na tym polu z nazistami ${ }^{53}$.

${ }^{50}$ J.T. Gross, Saciedzi, Sejny 2000 (wydanie angielskie: Neighbors: The Destruction of the Jewish Community in Jedwabne, Poland, 2002); idem, Fear. Anti-semitism in Poland after Auschwitz, New York 2006; wydanie polskie: Strach. Antysemityzm w Polsce tuż po wojnie, Kraków 2008.

${ }^{51}$ J. Grabowski, Ja tego Żyda znam. Szantażowanie Żydów w Warszawie 1939-1943, Warszawa 2004; idem, Polscy zarządcy powierniczy majątku żydowskiego. Zarys problematyki, „Zagłada Żydów. Studia i Materiały” 2005, t. 1, s. 253-260.

52 Por. przyp. 23.

${ }^{53}$ Np. dotyczy to muzykologa Ramułta - Treuhändera (zarządcy komisarycznego) żydowskich księgarni i wypożyczalni książek w Warszawie, zob. E. Assbury, op. cit., s. 267. 
Można stwierdzić ponad wszelką wątpliwość, że szczególną rolę odgrywał tu jeden czynnik, którego znaczenie podkreślali i Gross, i Grabowski: widoczna już przed wojną tendencja do wykluczania Żydów ze społeczeństwa polskiego w latach okupacji znacząco przybrała na sile. Taka postawa sprzyjała przyzwoleniu na przywłaszczanie mienia „pożydowskiego”, bez względu na to, czy było to mieszkanie, towary, meble, srebra stołowe o mniejszej wartości czy obrazy.

Analizując historię warszawskiego rynku sztuki przed Powstaniem Warszawskim, znajdziemy potwierdzenie tych okoliczności. Wiadomo, że w latach 19421944 na tym rynku nastąpiło znaczne ożywienie ${ }^{54}$. Jego oczywistą przyczyną była likwidacja getta warszawskiego. Wszystkie nowo założone „aryjskie” galerie i antykwariaty, które zajęły miejsce zlikwidowanych żydowskich, czerpały korzyści z kontaktów z gettem. Nasuwa się kluczowe pytanie: ile i które spośród tych nowych firm traktowały żydowskich właścicieli względnie uczciwie, a ile, które i do jakiego stopnia wykorzystywały ich beznadziejną sytuację ${ }^{55}$ ?

Emanuel Ringelblum pisał, że samozwańczy posiadacze traktowali Żydów jak „nieboszczyków na urlopie”, którzy i tak wkrótce zginą ${ }^{56}$. To bolesne porównanie wydaje się niestety celnie określać typowy stosunek Polaków do mienia „pożydowskiego" "57. Często zgodnie z tą maksymą „polonizowano” je jeszcze za życia właścicieli, a nagminnie i bez zahamowań po ich prawdopodobnej śmierci w myśl oczywistego motta: lepiej wziąć samemu, niżby miało się dostać w ręce Niemców ${ }^{58}$.

Następująca historia może posłużyć za przykład takiej postawy. Pan M. był przed wojną bogatym polskim przedsiębiorcą oraz dobrym klientem Abe Gutnajera - jednego z najbardziej renomowanych przedwojennych warszawskich marszandów. W 1940 r. Gutnajer wraz z rodziną przeniósł się do getta, ukrywszy swoje zbiory po „aryjskiej stronie”, prawdopodobnie z pomocą pana M. Pan M. miał zgodnie ze wskazówkami Gutnajera sukcesywnie wyprzedawać obrazy i przesyłać pieniądze (lub żywność albo inne artykuły pierwszej potrzeby) Gutnajerom do getta. Wziąwszy pod uwagę, że pan M. wiele ryzykował, nie byłoby nieetyczne, gdyby otrzymywał prowizję od swoich usług. W kwietniu 1942 r., w przededniu wielkiej akcji wysiedleńczej w getcie, rodzinę Gutnajerów zamordowano. Pan M. pozostał nadal aktywny w okupacyjnym handlu sztuką. Tuż po wyzwoleniu Warszawy w styczniu

${ }^{54}$ S. Bołdok, op. cit., s. 166-175 oraz „Słownik antykwariatów, salonów i domów aukcyjnych", s. 183-432.

${ }^{55} \mathrm{Z}$ jednej strony istniał Salon Sztuki Zofii Leśniewskiej, od listopada 1940 r. posiadający nawet swoją filię w getcie warszawskim, która miała służyć jako zasłona dymna przygotowań do ucieczek z getta (S. Bołdok, op. cit., s. 276 n.). Z drugiej strony, podziemie polskie napiętnowało kilka polskich antykwariatów znanych $z$ bezwzględnego bogacenia się kosztem Żydów. Jak trudne do zbadania są te sprawy, świadczy fakt, że na temat antykwariatu Leśniewskiej zachowały się sprzeczne świadectwa.

${ }^{56}$ E. Ringelblum, Stosunki polsko-żydowskie w czasie drugiej wojny światowej. Uwagi i spostrzeżenia, Warszawa 1988, s. 65.

57 J. Grabowski, Ja tego Żyda..., s. 129.

${ }^{58}$ J.T. Gross, Strach..., s. 84 nn. 
1945 r. otworzył własny antykwariat. Utrzymywał, że jego przedwojenna kolekcja cudem ocalała, dzięki czemu mógł rozkręcić swój powojenny interes ${ }^{59}$.

Syn Abe Gutnajera, Ludwik, walczył w Wojsku Polskim w 1939 r., dostał się do niewoli sowieckiej, dołączył do polskich oddziałów stacjonujących w Wielkiej Brytanii $^{60}$. Po wojnie wyjechał do USA. Na początku lat sześćdziesiątych odwiedził Polskę. Od syna nieżyjącego już wówczas pana M., także prowadzącego antykwariat, usłyszał, że ta część zbiorów Gutnajera, która nie uległa zniszczeniu w 1939 r., została wyprzedana do końca podczas okupacji w celu zapewnienia utrzymania zamkniętemu w getcie ojcu Ludwika, Abemu, wraz z resztą jego rodziny. Ludwik Gutnajer opuścił Polskę z kupionymi trzema obrazkami Nikifora. W 2008 r. spadkobiercy Ludwika odzyskali obraz z przedwojennych zbiorów Abe Gutnajera, który wypłynął w londyńskim domu aukcyjnym Sotheby's ${ }^{61}$.

\section{Po wojnie}

Już w 1943 r. w raporcie wysłanym z okupowanego kraju do Ministerstwa Spraw Zagranicznych Rządu RP na uchodźstwie w Londynie stwierdzano: „Powrót Żydów na ich dawne posady oraz do dawnych warsztatów jest niemożliwy, nawet jeśli wziąć pod uwagę fakt, że zostali zdziesiątkowani. Ludność nieżydowska zajęła ich miejsce w miasteczkach i miastach. Na przeważającej części terytorium Polski zmiany te mają charakter ostateczny. Powrót mas Żydów postrzegano by nie jako powrót do stanu rzeczy sprzed wojny, lecz jako agresję, przed którą Polacy są gotowi się bronić, nawet czynnie" 62 .

Szacuje się, że Zagładę przeżyło od 300 do 350 tys. polskich Żydów, co stanowi od 8 do 10 proc. ich liczby sprzed wojny. Na terytorium Polski, które od 1939 r. znajdowało się pod okupacją niemiecką, przeżyło ok. 50 tys. Żydów. Na ziemiach wschodnich włączonych do Związku Sowieckiego w 1939 r. i okupowanych przez Niemców w latach 1941-1944 liczba ocalałych Żydów była niewiele większa. Około 170 tys. polskich Żydów repatriowano z terytoriów sowieckich w pierwszych latach po wojnie. Z Niemiec i innych krajów Europy Zachodniej wróciło do kraju nie więcej niż 40 tys. obywateli polskich narodowości żydowskiej ${ }^{63}$.

${ }^{59}$ S. Bołdok, op. cit., s. 283.

${ }^{60}$ W. Kalicki, Świadek tylko czyta, „Gazeta Wyborcza”, 21 IV 2008.

${ }^{61}$ N. Cieślińska-Lobkowicz, Der blinde Fleck. Raubkunst, Restitution und „Ostjuden”, „Osteuropa” 2009, t. 1 , s. 77-78; S. Bołdok, op. cit., s. 169, 204, 229, 233, 283 n.

${ }^{62}$ Raport Romana Knolla, Polskie Ministerstwo Spraw Zagranicznych w Londynie, sierpień 1943 r. [w:] R. Chesnoff, Pack of Thieves. How Hitler and Europe Plundered the Jews and Committed the Greatest Theft in the History, London 1999, s. 179.

${ }^{63}$ Różne źródła podają nieco inne liczby. Te różnice spowodowane były nieprzerwaną w pierwszych latach po wojnie, legalną i nielegalną emigracją Żydów do Palestyny w ramach tzw. Brichy (ucieczki). Centralny Komitet Żydów w Polsce (CKŻP) podawał, że w 1946 r. było w Polsce 192 tys. Żydów, a trzy lata później 110 tys. 
22 lipca 1944 r., gdy znaczna część Polski nadal znajdowała się pod okupacją niemiecka, w wyzwolonym Lublinie został ogłoszony „Manifest” Polskiego Komitetu Wyzwolenia Narodowego (PKWN). Ten akt założycielski powojennego „ludowego” państwa polskiego gwarantował, że „Żydom po bestialsku tępionym przez okupanta zapewniona zostanie odbudowa ich egzystencji oraz prawne i faktyczne równouprawnienie"64.

Dwa tygodnie później powstał Centralny Komitet Żydów Polskich (CKŻP) ${ }^{65}$. Już w pierwszym jego protokole z 12 sierpnia 1944 r. zapisano, że „dziewięćdziesięciu Żydów zamieszkałych we Włodawie prosi o zabezpieczenie ich przed napadami elementów destrukcyjnych”66. „Elementy destrukcyjne” to eufemistyczne określenie polskich mieszkańców Włodawy, przed wojną typowego sztetla, w którym Żydzi stanowili połowę niemal dziesięciotysięcznej ludności. Ogromna większość włodawskich Żydów zginęła w Sobiborze. Garstka ocalałych chcących wrócić do swoich domów została dotkliwie pobita.

Dzięki książkom Grossa wiemy już dziś dobrze, że wrogość wobec ludzi, którzy cudem uniknęli Zagłady, w pierwszych latach po wojnie wśród Polaków szczególnie chłopstwa i drobnego mieszczaństwa - była zjawiskiem niepokojąco częstym $^{67}$. Zamordowano wówczas co najmniej kilkaset niedoszłych ofiar Szoa ${ }^{68}$. W sierpniu 1945 r. doszło do pogromu w Krakowie, w lipcu 1946 r. w Kielcach. W latach 1948-1949 Polskę w panice opuściło ponad 100 tys. Żydów uratowanych z Holokaustu.

Gross stwierdza, że jednym z głównych powodów tej wrogości i przemocy wobec Żydów, oczywistym dla wielu ówczesnych polskich obserwatorów, było nielegalne zawłaszczenie mienia żydowskiego podczas wojny i zaraz po niej ${ }^{69}$. Zajmowano domy, mieszkania i wszelkie inne nieruchomości. Brano meble, przedmioty gospodarstwa domowego, obrazy, wyposażenie warsztatów i fabryk, wyciągano

${ }^{64}$ „Żydom po bestialsku tępionym przez okupanta zapewniona zostanie odbudowa ich egzystencji oraz prawne i faktyczne równouprawnienie”; zob. www.trybunal.gov.pl/wszechnica/akty/manifest_pkwn.htm.

${ }^{65}$ CKŻP został powołany formalnie 12 XI 1944 r. jako następca Tymczasowego CKŻP i istniał do 1950 r. Był organizacją świecką, podlegały mu wcześniej już założone komitety terenowe. Stanowił reprezentację kilku partii żydowskich, w tym także przedwojennych, choć bez religijnych, których nie zalegalizowano, i z rosnącą przewagą partii komunistycznej PPR. Podlegały mu praktycznie wszystkie zagadnienia życia żydowskiego w kraju. Od 1946 r. był finansowany głównie przez Joint, którego oddział w kraju reaktywowano w 1945 r., w mniejszym stopniu także przez inne organizacje żydowskie.

${ }^{66}$ J.T. Gross, Strach..., s. 49.

${ }^{67}$ Ibidem, s. 39.

${ }^{68}$ „Najostrożniejsze, zachowawcze rachunki oscylują między 500 a 600; według powszechnie akceptowanych szacunkowych obliczeń ofiar było ok. 1500”, ibidem, s. 35 . Według R. Chesnoffa, op. cit., s. 178, zamordowano 2500 Żydów. Od redakcji: jest to oszacowanie zdecydowanie za wysokie.

${ }^{69}$ Gross, Strach..., szczególnie podrozdział „Przejmowanie żydowskiej własności przez osoby prywatne”, s. 84-92. 
poukrywane w zrujnowanych bóżnicach, w gettach i na cmentarzach rytualne srebra, nie mówiąc o zawłaszczeniu oddanych na przechowanie cennych rzeczy oraz o makabrycznej żyle złota i kosztowności na przeszukiwanych latami terenach obozów zagłady.

Nielegalne przejmowanie pożydowskiego mienia odbywało się za milczącym przyzwoleniem państwowej władzy. Poprzez inicjatywy prawne i własną działalność na tym polu usprawiedliwiała ona takie praktyki, a nawet do nich zachęcała, przeprowadzając na szeroką skalę ideologicznie motywowane upaństwowienie prywatnych firm, nieruchomości i ziemi.

Niewątpliwie zresztą państwo polskie stało się głównym beneficjentem „pożydowskiego" majątku: zarówno prywatnego, jak i należącego do gmin wyznaniowych oraz różnych żydowskich organizacji, instytucji i stowarzyszeń. Podstawę prawną stanowiły wydane w 1945 i 1946 r. przepisy o majątkach opuszczonych, porzuconych i poniemieckich ${ }^{70}$. Zgodnie z nimi wszystko, co podpadało pod te kategorie, przechodziło na własność skarbu państwa, przy czym określenie „opuszczony” odnosiło się w praktyce niemal wyłącznie do własności żydowskiej.

Co do mienia prywatnego, dekret z 8 marca 1946 r. przewidywał ostateczny termin zgłaszania roszczeń indywidualnych do 31 grudnia 1947 roku (prolongowany potem o rok). Zważywszy masowość polskich ofiar Szoa, powojenny chaos, wspomniane już powszechne agresywnie antysemickie nastroje w kraju oraz wprowadzoną zapewne nieprzypadkowo 8 października 1947 roku ustawę ograniczającą krąg spadkobierców do najbliższych krewnych, widoczne jest cyniczne ostrze tych przepisów wymierzone w ocalałych z Zagłady, a bezsporne profity państwa z przejmowania prywatnego mienia Żydów nie wymagają dalszego uzasadnienia ${ }^{71}$.

W podobny sposób postępowano z ocalałymi resztkami żydowskiej spuścizny kulturalnej. Zabytkowe nieruchomości gmin wyznaniowych przeszły pod zarząd państwowy. Uratowane ruchome dobra kultury: dzieła sztuki, judaika, książki i archiwa zależnie od okoliczności ich odnalezienia przejmowały instytucje państwowe lub osoby prywatne ${ }^{72}$.

Głównymi zadaniami Centralnej Żydowskiej Komisji Historycznej (CŻKH), założonej przy CKŻP w sierpniu 1944 r., było zbieranie świadectw dotyczących Zagłady i ratowanie żydowskiego dziedzictwa kulturalnego ocalałego w kraju i wywiezio-

${ }^{70}$ Ustawy z 6 V i 23 VII 1945 r. o majątkach opuszczonych i porzuconych (Dz.U. nr 17 z 1945 r., poz. 97 i nr 30, poz. 179) i ostateczny Dekret z 8 III 1946 r. o majątkach opuszczonych i poniemieckich. (Dz.U. nr 13 z 1946 r., poz. 87).

${ }^{71}$ Zob. R. Chesnoff, op. cit., s. $180 \mathrm{n}$.

${ }^{72} \mathrm{~W}$ przeciwieństwie do nieruchomości, $\mathrm{z}$ wielu skomplikowanych powodów nigdy nie dokonano poważnych szacunków zagrabionych ruchomych dóbr kultury należących do polskich gmin żydowskich oraz polskich Żydów. Książka Chesnoffa wydana w 1999 r. (op. cit., w szczególności rozdział „Poland: Forever Strangers”, s. 164-184 ) nie może służyć za źródło wyliczeń, podobnie jak spisy strat poniesionych w czasie wojny sporządzone podczas wojny lub zaraz po niej (zob. przyp. 7). 
nego za granicę ${ }^{73}$. Jej filie powstały w wielu miastach, przede wszystkim tam, gdzie w czasie okupacji istniały większe getta ${ }^{74}$. W październiku 1947 r. CŻKH przekształcono w Żydowski Instytut Historyczny (ŻIH).

Opis historii oraz działalności CŻKH/ŻIH wykracza poza ramy niniejszego tekstu $^{75}$. Niemniej jednak trzeba podkreślić, że nie tylko dla władz państwowych i samego Centralnego Komitetu Żydów Polskich, ale również dla Jointu (American Jewish Joint Distribution Committee) i kilku innych międzynarodowych organizacji żydowskich CŻKH/ŻIH był historycznym i kulturalnym dziedzicem polskich Żydów i do tej instytucji należała opieka nad zabytkowym żydowskim mieniem ${ }^{76}$. Nieprzypadkowo CŻKH od momentu powstania archiwizowała dokumenty, prowadziła bibliotekę i zbierała eksponaty do planowanego muzeum ${ }^{77}$.

Lokalne oddziały Centralnej Żydowskiej Komisji Historycznej szukały osieroconych dóbr kultury w całym kraju. Na przykład w 1947 r. wrocławska ŻKH odkryła w Sławniowcach (niem. Kunzeldorf) niedaleko Bystrzycy Kłodzkiej (niem. Habelschwerdt) 20 tys. książek po hebrajsku i w jidysz oraz archiwaliów zrabowanych przez nazistów dla RSHA. Część tych zbiorów pochodziła z warszawskiej Głównej Biblioteki Judaistycznej, część z wrocławskiego Żydowskiego Seminarium Teologicznego (Jüdisch-Theologisches Seminar) ${ }^{78}$. W styczniu 1948 r. znalezisko przekazano warszawskiej bibliotece ŻIH-u. Inny fragment zbiorów Biblioteki Judaistycznej odnaleziono w czeskim zamku Mimoń niedaleko Liberca i w zamku Houska w Českiej Lípie (tu odnaleziono też fragmenty innych polskich księgozbiorów, m.in. Biblioteki Sejmu i Senatu). Książki wróciły do kraju w listopadzie 1946 r. Te, które pochodziły z żydowskich książnic, przekazano wkrótce do biblioteki ŻIH-u ${ }^{79}$. Tak samo postąpiono z książkami hebrajskimi znajdującymi się wśród

${ }^{73} \mathrm{Z}$ prośbą o poszukiwanie i rewindykację żydowskich zabytków i archiwaliów z amerykańskiej strefy okupacyjnej Niemiec CŻKH zwróciła się do Karola Estreichera zajmującego się restytucją wywiezionych z Polski dóbr kultury; zob. list CŻKH z 12 marca 1947 r. [w:] K. Estreicher, op. cit., s. 841.

${ }^{74}$ N. Grüss, Rok Pracy Centralnej Żydowskiej Komisji Historycznej, Łódź 1946, s. 5. Dalsze uwagi na temat CKŻH oparto na pracy Grüssa.

${ }^{75}$ Więcej na ten temat zob. A. Żbikowski, Żydowski Instytut Historyczny. 50 lat działalności, Warszawa 1996. Zob. też www.jewishinstitute.org.pl.

${ }^{76}$ Dopóki pozwalały na to komunistyczne władze. W 1946 r. CŻKH współpracowała z Żydowskim Instytutem Historycznym w Londynie, New York Institute of Jewish Affairs i z Yad Vashem w Palestynie, zob. N. Grüss, op. cit., s. 23.

${ }^{77} \mathrm{CŻKH}$ uważała swoją bibliotekę za sukcesora Głównej Biblioteki Judaistycznej. Dlatego przeniesienie CŻKH z Łodzi do pierwotnej, warszawskiej siedziby biblioteki na Tłomackiem, które odbyło się pod koniec 1947 r., miało głęboko symboliczne znaczenie; zob. N. Grüss, op. cit., s. 14-16.

${ }^{78}$ M. Sieramska, op. cit. s. 8; A. Mężyński, op. cit., s. 95.

${ }^{79}$ A. Mężyński, op. cit., s. 95. W „Opisowym katalogu zagrabionych judaików”, w części poświęconej Polsce (zob. www.claimscon.org), czytamy: „Według prof. Shmuelsa Huga Bergmanna z Uniwersytetu Hebrajskiego, który był świadkiem owego transportu, przedstawiciele polskich władz żądali zwrotu nawet [podkreślenie moje - N. C.-L.] książek z Głównej 
polskich zasobów bibliotecznych w osiemdziesięciu dwóch skrzyniach, które udało się odzyskać Karolowi Estreicherowi z amerykańskiej strefy okupacyjnej Niemiec we wrześniu 1947 r. ${ }^{80}$.

Ten ostatni przypadek jest o tyle ważny, że wkrótce Amerykanie zmienili politykę restytucyjną wobec zrabowanej przez nazistów na Wschodzie Europy własności żydowskiej ${ }^{81}$. Odeszli od zgodnej z prawem międzynarodowym zasady odsyłania zrabowanych dóbr do państwa ich pochodzenia, którego władze z kolei zobowiązane są do ich zwrotu prawowitym właścicielom. Obok powodów natury ogólniejszej, związanych z początkiem zimnej wojny, asymetrią amerykańskiej i sowieckiej polityki restytucyjnej, chodziło i o to, że polskie władze nie zwracały odzyskanych obiektów ich prywatnym właścicielom, nie mówiąc o informacjach o antysemickich ekscesach w Polsce i bezprawnym przejmowaniu „pożydowskiego" mienia ${ }^{82}$.

W tym kontekście warto jednak przypomnieć szczególny status i zadania CŻKH/ ŻIH w odniesieniu do żydowskich zabytków ruchomych uratowanych w Polsce. Mimo że instytucja ta działała w warunkach państwa komunistycznego, początkowo pełniła podobne funkcje jak dwie żydowskie organizacje aktywne wówczas w USA i w amerykańskiej strefie okupacyjnej Niemiec - Jewish Cultural Reconstruction (JCR) oraz Jewish Reconstruction Successor Organisation (JRSO), które stały się depozytariuszami odnalezionego w strefie amerykańskiej bezpańskiego mienia żydowskiego zrabowanego przez nazistów ${ }^{83}$.

Na podobnej zasadzie ŻIH otrzymał w 1949 r. od Muzeum Okręgowego w Toruniu, a także od warszawskiego Muzeum Narodowego (w 1951 i 1953 r.) oraz z muzeum na zamku w Lublinie (w 1952 r.) przechowywane tam judaika skonfiskowane

Biblioteki Judaistycznej”. Według informacji udzielonych autorce artykułu przez p. Hannę Łaskarzewską z Biblioteki Narodowej (BN) w Warszawie, w archiwach BN zachował się list jej ówczesnego dyrektora Józefa Grycza, dotyczący przekazania do ŻIH-u warszawskich książek żydowskich z BN, gdzie początkowo znalazły się wszystkie restytuowane zbiory.

${ }^{80}$ Z.K. Witek, Dokumenty strat kultury polskiej pod okupacja niemiecka 1939-1945 $z$ archiwum Karola Estreichera, Kraków 2003, s. 550. Dokumentacja Wydziału Rewindykacji i Odszkodowań przy MKiS została w dużej mierze zniszczona na początku lat pięćdziesiątych. Z sowieckiej strefy okupacyjnej Niemiec zwrócono nieznaną liczbę dóbr należących do różnych wspólnot wyznaniowych (z wyjątkiem Kościoła katolickiego); zapewne były wśród nich także judaika. Zob. L. Bończa-Bystrzycki, Grabież mienia zwiazków wyznaniowych na ziemiach polskich „wcielonych” do Rzeszy w okresie hitlerowskiej okupacji 1939-1945, Koszalin 1999, s. 161 i 169.

${ }^{81}$ Chodzi o OMGUS Law 59 z 10 XI 1947; OMGUS to skrót nazwy wojskowej administracji w amerykańskiej strefie okupacyjnej Niemiec: Office of Military Government U.S. Zone (Germany).

${ }^{82}$ Michael J. Kurtz odnosi się tu do „powszechnych skarg ze strony polskich grup religijnych na rząd komunistyczny, który nie zwracał majątku kościelnego prawowitym właścicielom”. Zob. idem, America and the Return of Nazi Contraband, Cambridge - New York 2006, s. 187.

${ }^{83}$ Zob. M.J. Kurtz, op. cit., s. 161 n., por. także dalej uwagi o JCR I JRSO. 
przez Niemców ${ }^{84}$. Obok wspomnianego już wcześniej odzyskania judaików z Czechosłowacji, które trafiły do wrocławskiej ŻKH, Ministerstwo Kultury przekazało Instytutowi we wrześniu 1953 r. znalezisko z zamku Narożno niedaleko Bożkowa na Dolnym Śląsku. Był to bogaty zbiór judaików, żydowskich książek oraz archiwaliów pochodzących głównie z berlińskiego Muzeum Żydowskiego i tamtejszej gminy wyznaniowej ${ }^{85}$.

W latach stalinowskich CKŻP zdecydował o dołączeniu do tego także zbiorów rozwiązanego w 1949 r. Żydowskiego Towarzystwa Krzewienia Sztuk Pięknych. Również Polska filia Jointu, którą zamknięto w 1950 r., przekazała ŻIH-owi zgromadzoną w okresie kilkuletniej działalności niewielką kolekcję judaików ${ }^{86}$.

Dwa wydarzenia związane z polityką CKŻP i CŻKH/ŻIH wydają się szczególnie interesujące. W grudniu 1947 r. „Menachen Mendel Schneurson, ówczesny skarbnik Uniwersytetu Hebrajskiego, działał w Polsce, skąd usiłował wysłać 85 tys. książek rabinicznych do Jerozolimy"87. W niedawno opublikowanej po hebrajsku książce Płonace zwoje i ulatujące litery Dov Schidorsky napisał, że była to w większości „literatura religijna, tysiące modlitewników”88. Choć Schneurson negocjował głównie z CKŻP, kontaktował się też z przedstawicielami polskich władz państwowych. Według Schidorsky’ego „książki te należały do CKŻP, który od momentu wyzwolenia Lublina miał za zadanie je gromadzić. CKŻP wybrał bardziej wartościowe książki do nowej Głównej Biblioteki Judaistycznej [ŻIH] w Warszawie, którą miała być otwarta w 1948 r., natomiast do Jerozolimy wysłano między innymi wiele tomów z biblioteki jesziwy »Mędrców Lublina«, oraz trochę manuskryptów i druków z wrocławskiego Żydowskiego Seminarium Teologicznego"89.

Drugie wydarzenie dotyczy przedmiotów uratowanych z getta łódzkiego przez Nachmana Zonabenda ${ }^{90}$. Obok najróżniejszych dokumentów było wśród nich m.in. pięćdziesiąt obrazów Józefa Kownera (które Zonabend zwrócił ocalałemu artyście),

${ }^{84}$ M. Sieramska, Muzeum Żydowskiego Instytutu Historycznego - zbiory i działalność [w:] Żbikowski, op. cit., s. 55-56; R. Piątkowska, M. Sieramska, Wstęp [w:] Muzeum Żydowskiego Instytutu Historycznego. Zbiory artystyczne, Warszawa 2000, s. 6. Lubelskie muzeum odesłało do ŻIH-u tylko część judaików przechowywanych tam w czasie okupacji.

${ }^{85}$ M. Sieramska, $Z$ problematyki..., s. 9; były tam też przedmioty rytualne należące do greckich Żydów, którzy zginęli w Auschwitz.

${ }^{86}$ M. Sieramska, Muzeum..., op. cit., s. 56.

${ }^{87}$ D. Schidorsky, The Salvaging of Jewish Books in Europe after the Holocaust [w:] Jüdischer Buchbesitz als Raubgut, s. 205.

${ }^{88}$ D. Schidorsky, Gewilim nisrafim we-otijot-porhot, Jerusalem 2008, s. 274-278. Dziękuję dr. Schidorsky'emu za tę informację oraz dalsze informacje pochodzące z jego hebrajskiej publikacji, którą uprzejmie streścił mi w e-mailu ze stycznia 2009 r.

${ }^{89}$ Przekazanie tych książek do Jerozolimy odbyło się wtedy, gdy komunistyczny rząd Polski zgodnie ze swoją antyreligijną polityką pozwolił niektórym rabinom oraz wielu ortodoksyjnym Żydom na emigrację z Polski do Izraela, a nawet ich do tego przez krótki czas nakłaniał.

${ }^{90}$ Informacje te pochodzą z N. Zonabend, The Truth about saving of the Łódź Getto Archive, Stockholm 1991. 
siedemdziesiąt obrazów Maurycego Trębacza oraz prace Izraela Lejzorowicza, Amosa Szwarca, Mendla Grosmana i innych. Zonabend oddał część ocalałych dzieł i materiałów w ręce kierownika CŻKH, dr. Filipa Friedmana. Pozostałe zabrał do Szwecji, dokąd wyemigrował w 1947 r. i skąd część wysłał do Jidiszer Wisnszaftlecher Institut (YIVO) w Nowym Jorku (w ten sposób powstała Kolekcja Nachmana Zonabenda) i do Yad Vashem w Jerozolimie (Osef - Dar z kolekcji Zonabenda). Zabierając ze sobą na emigrację te uratowane z getta materiały, Zonabend występował przeciwko prawu PRL, które zabraniało wywożenia za granicę wszelkich cennych dóbr kultury ${ }^{91}$. Władze polskie zdecydowanie sprzeciwiały się amerykańskiej polityce restytucji, zgodnie z którą wspomniane wcześniej JCR i JRSO uznano za legalnych sukcesorów pozbawionego spadkobierców mienia odnalezionego w amerykańskiej strefie okupacyjnej Niemiec ${ }^{92}$. Obie organizacje opowiadały się stanowczo przeciwko zwrotom mienia żydowskiego do Polski i innych państw Europy Wschodniej, skąd zniknęły prawie wszystkie gminy żydowskie i gdzie otwarcie manifestowano antysemityzm. Zdecydowały się podzielić otrzymane od Amerykanów w końcu lat czterdziestych „bezpańskie” judaika, pochodzące głównie z terenów Rzeszy i krajów Europy Wschodniej, między gminy wyznaniowe, organizacje i muzea żydowskie, przede wszystkim w Izraelu i USA. W takim kontekście politycznym ukazał się w polskiej gazecie żydowskiej artykuł pełen zniewag pod adresem Zonabenda, który przedrukowano następnie w prasie komunistycznej w Kanadzie i Francji ${ }^{93}$. Oczywistą przyczyną tych ataków była antyamerykańska polityka ery zimnej wojny. Tym bardziej znaczący jest fakt, że żaden z członków CŻKH nie przyłączył się do ataków na Zonabenda. Widać rozumieli oni, a być może nawet popierali jego decyzję o podziale zbiorów ocalonych z getta łódzkiego między Warszawę, Nowy Jork i Jerozolimę.

Ostatnie dwa przykłady dotyczą dzieł sztuki, których właściciele przeżyli Zagładę. Jak już wcześniej wspomniałam, w okresie wojny w warszawskim Muzeum Narodowym (MN) znalazły się prywatne depozyty, z których część złożona przez żydowskich kolekcjonerów miała pro forma charakter darów. Stanisław Lorentz, funkcję dyrektora MN sprawujący nieprzerwanie przez wiele lat - także podczas okupacji, kiedy ówczesne Stadtmuseum nadzorował niemiecki komisarz - i będący spiritus movens działalności podziemnej w zakresie kultury, ratowania zabytków i dokumentacji strat wojennych, zachowywał się w stosunku do Żydów i ich mienia w sposób przykładny ${ }^{94}$. Część zbiorów MN naziści wywieźli już w 1939 r. i na początku 1940 r., by w 1944 r. po Powstaniu Warszawskim ponownie dopuścić się grabieży. Wśród obiektów, które przetrwały w budynku MN, odnalezionych na

${ }^{91}$ Dekret z 1 III 1946 r. o rejestracji i zakazie wywozu dzieł sztuki plastycznej oraz przedmiotów o wartości artystycznej, historycznej lub kulturalnej (Dz.U. Nr 14 z 1946 r., poz. 99).

${ }^{92}$ M.J. Kurtz, op. cit., s. 200 n.

${ }^{93}$ Aleksander Klugman tak pisał o Zonabendzie w „Dos Naye Lebn”: „Gestapowiec, który w Nowym Jorku stał się męczennikiem”, N. Zonabend, op. cit.

${ }^{94}$ Zob. N. Cieślińska-Lobkowicz, Walka w obronie polskich dobr kultury w czasie wojny i okupacji hitlerowskiej, „Kronika zamkowa” 2008, nr 1-2 (55-56), s. 159-168. 


\section{$112 \quad$ Studia}

Dolnym Śląsku i rewindykowanych przez Amerykanów z Niemiec i Austrii, znajdowały się także żydowskie depozyty. Zwracono je zgłaszającym się po nie właścicielom $^{95}$.

Bronisławowi Krystallowi oddano kilkanaście wartościowych obrazów: część w 1946 r., a pozostałe trzy lata później, gdy wróciły do Polski z innymi skradzionymi z MN obrazami odzyskanymi na zamku Fischhorn w Austrii. W następnych latach zubożały kolekcjoner był zmuszony sprzedać MN kilka swoich obrazów, resztę podarował tej instytucji pod koniec życia.

Siostry Goldberg-Górskie otrzymały z powrotem wszystkie dziewięćdziesiąt dwa przedmioty zdeponowane w MN. Zdecydowały się wówczas przekazać je Muzeum w depozyt, a w 1968 r. zapisały je MN w spadku' ${ }^{96}$.

W latach 1947-1948 Ignacy Landstein odzyskał pięć z piętnastu obrazów, które ukrył w MN podczas okupacji. Pozostałych dziesięciu nie odnaleziono. Jeden ze zwróconych obrazów przekazał Muzeum w darze.

Uczynił to także w 1945 r. Andrzej Rotwand, którego znana kolekcja malarstwa została skonfiskowana przez gestapo, złożona w budynku MN i częściowo wywieziona do Austrii. Po wojnie odzyskał najpierw sześć płócien przechowanych w MN, kolejne zaś po ich przewiezieniu do kraju z Fischhorn. Muzeum zakupiło wtedy od niego jeden obraz, drugi nabyło w 1951 r. od wdowy po zmarłym już wówczas kolekcjonerze.

Wydaje się, że podobną politykę restytucyjną prowadziła również Biblioteka Narodowa w Warszawie ${ }^{97}$. Dopiero dzięki szczegółowym badaniom można będzie ustalić, czy stosowano ją konsekwentnie, jak długo i czy wobec wszystkich ocalałych właścicieli lub ich spadkobierców, którzy zgłosili się po swoje depozyty i „dary”. Otwarta pozostaje też kwestia, czy i do jakiego stopnia inne muzea i biblioteki w kraju działały wedle tych samych zasad, którymi kierował się prof. Lorentz.

Niewątpliwie jednak obowiązywały wspomniane wcześniej dekrety o majątkach opuszczonych, zgodnie z którymi nieposiadające prawowitych właścicieli depozyty, „dary” i przedmioty skonfiskowane przez nazistów przechodziły na własność muzeów i bibliotek, które wpisywały je do swoich inwentarzy. Tak stało się z uratowaną kolekcją rzemiosła artystycznego Janiny i Leopolda Binenthalów, którzy w 1940 r. „podarowali” ją warszawskiemu MN. Podobny los spotkał również księgozbiór wybitnego historyka prof. Marcelego Handelsmana (4 tys. tomów) oraz ko-

${ }^{95}$ Przyjaciele muzeum. Wystawa zorganizowana z okazji Międzynarodowego Dnia Muzeów ICOM-UNESCO, Warszawa 2003, s. 38-39, 44-45. Dalsze szczegółowe informacje dotyczące powojennej restytucji przedmiotów z warszawskiego Muzeum Narodowego opierają się na informacji przesłanej do autorki e-mailem w styczniu 2009 r. przez Głównego Inwentaryzatora warszawskiego MN, p. Lidię Karecką, której składam podziękowania.

${ }^{96}$ Nie wiadomo, czy w 1968 r. Goldberg-Górska napisała ów testament z własnej woli czy może sporządziła go przymuszona antysemicką polityką rządu. Władze zabraniały wywozu dzieł sztuki żydowskim emigrantom, którzy opuszczali kraj po wydarzeniach marcowych.

${ }^{97}$ Zob. A. Kawecka-Gryczowa, Ochrona zbiorów Biblioteki Narodowej [w:] Walka o dobra kultury. Warszawa 1939-1945, t. 1, s. 240. 
respondencję słynnego matematyka prof. Samuela Dicksteina i jego żony Pauline (ok. 5 tys. listów), którą w czasie wojny ich córka zdeponowała w Bibliotece Narodowej w Warszawie ${ }^{98}$. Z pewnością wiele podobnych przykładów można znaleźć w instytucjach kultury w całej Polsce, poczynając od krakowskiej Biblioteki Jagiellońskiej i biblioteki Uniwersytetu Adama Mickiewicza w Poznaniu, czy w muzeach Łodzi, Torunia i Lublina.

Odmienny casus wiąże się z osobą Józefa Stieglitza, syna słynnego krakowskiego marszanda, Abrahama. Zgodnie ze wspomnieniami Józefa, który zaraz po wojnie zamieszkał w Tel Awiwie - jego ojciec wróciwszy tuż po wojnie do Krakowa z ZSRR odzyskał część swojej kolekcji judaików, którą przed ucieczką na Wschód w 1939 r. zdeponował u zaprzyjaźnionego profesora99. Miał nim być przedwojenny kierownik konserwacji Wawelu, Adolf Szyszko-Bohusz, który zresztą odmówił przyjęcia od Stieglitza seniora jakiegokolwiek wynagrodzenia. Szyszko-Bohusz pisał natomiast, że to Stieglitzowi juniorowi, który przyjechał w listopadzie $1945 \mathrm{r}$. z Palestyny, zwrócił przechowane przez siebie jego zbiory ${ }^{100}$.

Tutaj jednak nasuwają się pytania i wątpliwości. Po pierwsze: co stało się z odzyskanymi zbiorami, skoro od 1946 r. obowiązywał wspomniany już zakaz wywozu dzieł sztuki z kraju? W Izraelu Stieglitz jun. zasłynął jako marszand i wybitny znawca judaików ${ }^{101}$. Pojawiły się poważne podejrzenia, że przynajmniej część „odzyskanej” ojcowskiej kolekcji judaików była w rzeczywistości własnością zgładzonych galicyjskich Żydów. Józef Stieglitz, działając we Lwowie, przez rok od lata $1941 \mathrm{r}$. na zlecenie holenderskiego nazisty i znanego grabieżcy Petera Mentena skupywał bowiem dzieła sztuki i rzemiosła od Żydów skazanych na zagładę ${ }^{102}$. Po ucieczce do Budapesztu, gdzie na polskich papierach doczekał wyzwolenia, nadal parał się podobnym procederem, czego dowodem wydaje się - równie pokaźna jak polska kolekcja węgierskich judaików w zbiorach przekazanych przezeń pod koniec życia Muzeum Izraela w Jerozolimie.

${ }^{98}$ Więcej o Binenthalu zob. Przyjaciele muzeum..., s. 23; Handelsman zob. E. Assbury, op. cit., s. 268; Dickstein zob. A. Kawecka-Gryczowa, op. cit., s. 210.

${ }^{99}$ R. Maiberg [w:] Ch. Benjamin, The Stieglitz Collection. Masterpieces of Jewish Art, Jerusalem 1987, s. 9 nn. [katalog wystawy w Muzeum Izraela].

100 A. Szyszko-Bohusz, Wawel pod okupacja niemiecka. Wspomnienia z lat 1939-1945, „Rocznik Krakowski” tom 31, Kraków 1949-1957 (Kraków w latach okupacji 1939-1945. Studia i materiaty), s. 162.

${ }^{101}$ Ch. Benjamin, op. cit.

102 D. Schenk, Der Lemberger Professorenmord und der Holocaust in Ostgalizien, Bonn 2007, s. 135-141, 165-167, 253-254. Na temat Mentena zob. również H. Knoop, The Menten Affair, New York 1978; M. MacPherson, The Last Victim. One Man's Search for Pieter Menten, His Family and Executioner, London 1984; E. Elovic, Till they meet again, Jerusalem 2007. 


\section{Wciąż nienapisany rozdział}

Jak pamiętamy, autorzy konspiracyjnego opracowania o stanie kultury w okupowanej Polsce już w 1942 r. uznali, że straty w postaci zagrabionych i zniszczonych zbiorów żydowskich wymagają oddzielnego opisu ${ }^{103}$. Jacob Apenszlak, przedwojenny publicysta i działacz kulturalny, który w 1923 r. założył Żydowskie Towarzystwo Krzewienia Sztuk Pięknych, w przygotowanej na emigracji w Nowym Jorku i wydanej w 1943 r. „Czarnej księdze polskiego żydostwa” (Black Book of Polish Jewry) także podkreślał ogrom strat zadanych przez nazistów kulturze jego narodu ${ }^{104}$.

Karol Estreicher, w czasie wojny twórca i kierownik Biura Rewindykacji Strat Kulturalnych rządu RP na uchodźstwie, w opublikowanym w Londynie w 1944 r. Wykazie strat kulturalnych Polski wymienił niektóre zniszczone i ograbione synagogi, zagrabione żydowskie biblioteki, głównie warszawskie i krakowskie, a także archiwa i prywatne kolekcje $\mathrm{e}^{105}$.

W 1946 r. JCR opublikowało „Wstępną listę żydowskich skarbów kultury na terytoriach okupowanych przez państwa Osi” (Tentative List of Jewish Cultural Treasures in Axis-occupied Countries) mającą służyć jako podstawa indentyfikacji i restytucji zrabowanych zbiorów. Duża część opracowania dotyczy terenów przedwojennej Polski. Publikacja ta stanowi po dziś dzień najbogatsze źródło informacji ${ }^{106}$. W kraju niedługo po wojnie wnikliwie o stratach judaików i dzieł artystów żydowskich pisał jedynie Józef Sandel, ale i jemu nie udało się wyjść poza bardzo ogólne dane. Potem na dziesiątki lat zapadło milczenie, przerywane nielicznymi monografiami zabytków żydowskich, w których niejako na marginesie uwzględniano kwestię zniszczeń wojennych.

W latach dziewięćdziesiątych - także po dziesięcioleciach milczenia - pod auspicjami Biura Pełnomocnika Rządu ds. Polskiego Dziedzictwa Kulturowego za Granicą przy Ministerstwie Kultury zaczęły się pojawiać publikacje dotyczące strat kulturalnych poniesionych przez Polskę w okresie wojny i okupacji, a także opracowania historyczne na ten temat. Skupiały się jednak tradycyjnie na dokumentowaniu strat narodowych i zapoznawały nadal odmienność losów „aryjskiego” i „niearyjskiego” mienia. Straty żydowskie traktowano zazwyczaj ogólnikowo, ewentualne bliższe dane powtarzano za Tentative List. Nieco więcej uwagi poświęcano bibliotekom, w szczególności losom Wielkiej Biblioteki Judaistycznej w Warszawie ${ }^{107}$. Całkowi-

103 Zob. przyp. 44.

${ }^{104}$ Zob. przyp. 5.

${ }^{105}$ Zob. Ch. Estreicher, Index of Polish Cultural Losses, przyp. 7.

${ }^{106}$ Zob. Tentative List..., przyp. 7. Najnowsze starania dotyczące judaików zrabowanych w Europie zostały podjęte przez Claims Conference against Germany. Jeden z rozdziałów poświęcony jest Polsce. Zob. opisowy katalog zrabowanych judaików na stronie internetowej www.claimscon.org.

${ }^{107}$ W szczególności zob. cytowane opracowania A. Mężyńskiego, także tegoż i H. Łaskarzewskiej, Biblioteki naukowe w Generalnym Gubernatorstwie w latach 1939-1945, Warszawa 2003. 
tym milczeniem natomiast publikacje te pomijały kwestie utraty obrazów wybitnych malarzy polskich i cenionych starych mistrzów, które - jak wspomniałam na początku - z upodobaniem kolekcjonowali przedstawiciele żydowskiej inteligencji i burżuazji ${ }^{108}$.

Zważywszy rosnącą od niemal dwudziestu lat falę zainteresowania historią i kulturą Żydów w Polsce, a także obszerne badania dotyczące Zagłady, zastanawia fakt, że nadal niewyjaśnione pozostaje pochodzenie zdecydowanej większości zbiorów zgromadzonych w ŻIH-u oraz judaików i dzieł artystów żydowskich w innych polskich muzeach, bibliotekach i archiwach, nie mówiąc o kolekcjach prywatnych. I że wydaje się to nikomu u nas nie przeszkadzać. Przekonują o tym liczne krajowe publikacje na temat kultury i sztuki Żydów polskich, których autorzy, powołując się na konkretne dzieła i obiekty znajdujące się obecnie w krajowych zbiorach, z zasady abstrahują od pytania o ich proweniencję ${ }^{109}$.

\section{Konkluzja}

Opisane tu skrótowo problemy oraz zobowiązania wynikające z podpisanych przed dziesięciu laty Zasad Waszyngtońskich, potwierdzone na konferencji zorganizowanej w Pradze w 2009 r. ${ }^{110}$, zdają się potwierdzać konieczność podjęcia w kraju kompleksowych badań nad tymi zagadnieniami. Powinny one pomóc wydobyć z zapomnienia nazwiska żydowskich kolekcjonerów i mecenasów i przywrócić im oraz ich zbiorom należne miejsce w historii kultury naszego kraju ${ }^{111}$. Badania te mogłyby też stanowić próbę odtworzenia przynajmniej niektórych kolekcji i bibliotek - zarówno tych, których spadkobierców da się jeszcze odnaleźć, jak i tych, które zostaną osierocone na zawsze.

Można żywić nadzieję, że dzięki takim badaniom mogłoby dojść do zwrotu choćby pojedynczych zidentyfikowanych obiektów z publicznych zbiorów prawowitym spadkobiercom ich przedwojennych żydowskich właścicieli, tak jak to od pewnego czasu dzieje się w przypadku niektórych kolekcji arystokracji lub ziemiaństwa, zarekwirowanych w ramach reformy rolnej. Byłoby to nie tylko zgodne z duchem i literą Zasad Waszyngtońskich, ale miałoby też znaczenie symboliczne.

${ }^{108}$ Zob. Straty wojenne. Malarstwo polskie. Obrazy olejne, pastele, akwarele utracone w latach 1939-1945 w granicach Polski po 1945, red. A. Tyczyńska, K. Znojewska, Poznań 1998; Straty wojenne. Malarstwo obce. Obrazy olejne, pastele, akwarele utracone w latach 1939-1945 bez Ziem Zachodnich i Pótnocnych, red. M. Romanowska-Zadrożna, T. Zadrożny, Poznań 2000, t. 1.

${ }^{109}$ Np. J. Malinowski, Malarstwo i rzeźba Żydów Polskich w XIX i XX wieku, Warszawa 2000, t. 1; I. Rejduch-Samkowa, J. Samek, Dawna sztuka żydowska w Polsce, Warszawa 2002.

${ }^{110}$ Holocaust Era Assets Conference in Prague on June 26-30.2009, i Terezin Declaration 30.06.2009; w interencie: www.holocausteraassets.eu.

${ }^{111} \mathrm{Z}$ tego, co wiem, trwają prace nad jedną pracą doktorską na ten temat. Dariusz Kacprzak pisze o łódzkich kolekcjonerach dzieł sztuki. 
Jednak najważniejszym celem takich badań jest przywrócenie w naszej zbiorowej pamięci ludzi, którzy tworząc i zbierając księgi i biblioteki, przedmioty kultu, dzieła sztuki i wyroby rzemiosła, współtworzyli kulturę Żydów w Polsce, kulturę polskich Żydów i - last but not least - kulturę polską. Od dawna jesteśmy im to winni.

Tłumaczenie z angielskiego: Anna Brzostowska i Jerzy Giebułtowski

\title{
Słowa kluczowe
}

restytucja mienia, dzieła sztuki, mienie żydowskie

\begin{abstract}
The article presents the problem of Jewish cultural property appropriated during the Second World War and attempts at describing the treatment of Jewish cultural property in Poland shortly after the war, i.e. during the first wave of the restitution process. Apart from the few cases of owners regaining the property owned before the war, the author describes appropriation of "nobody's Judaica" by state administration. It also draws attention to the necessity of research about either appropriated or damaged cultural property of Polish Jews and the post-war attempts to find and restitute it to their rightful owners or heirs.
\end{abstract}

\section{Key words}

property restitution, works of art, Jewish property 